\title{
DISCLAIMER
}

This report was prepared as an account of work sponsored by an agency of the United States Government. Neither the United States Government nor any agency thereof, Bur any of their employees, makes any warranty, express or implied, or assumes any legal liability or responsibility for the accuracy, completeness, or usefulness of any information, apparatus, product, or process disclosed, or represents that its use would not infringe privately owned rights. Reference herein to any specific commercial product, process, or service by trade name, trademark. manufacturer, or otherwise does not necessarily constitute or imply its endorsement, recommendation, or favoring by the United States Government or any agency thereof. The views and opinions of authors expressed herein do not necessarily state or reflect those of the United States Government or any agency thereof.

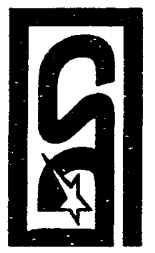

국쯤

$\stackrel{0}{0}$

$\circ$

공

옥

으으

C $\overrightarrow{\mathrm{B}}$

कृ

:

弯
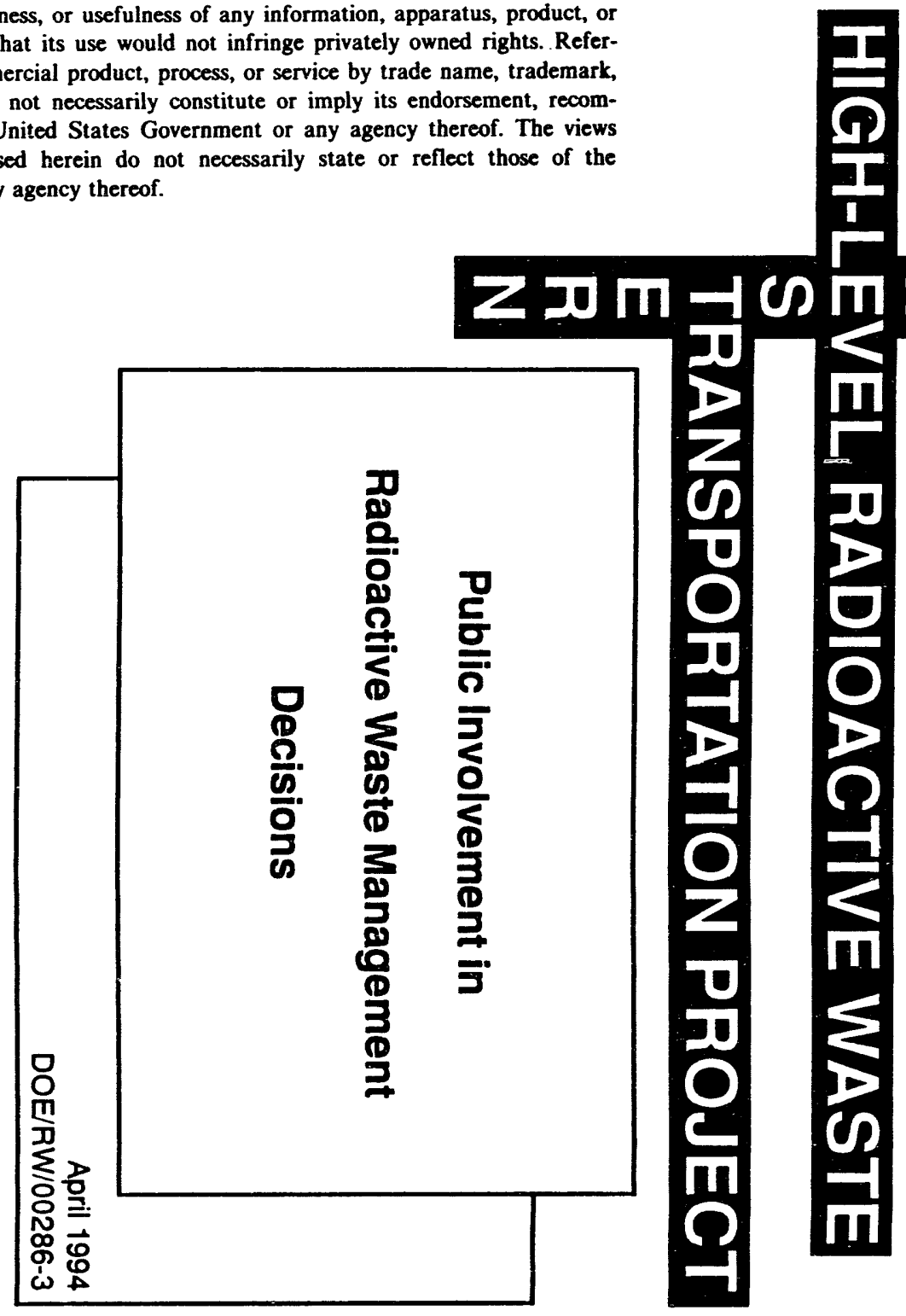


\section{The Council of State Governments}

For more than half a century, The Council of State Governments has served as a common ground for the states of the nation. The Council is a non-profit, state-supported and -directed service organization that provides research and resources, identifies trends, supplies answers and creates a network for legislative, executive and judicial branch representatives.

Through its national headquarters in Lexington, Kentucky, a state-federal office in Washington, D.C., and regional offices in New York, Atlanta, Chicago (Lombard), and San Francisco, CSG is dedicated to preserving the role of states in America's federal system.

The role of the Midwestern Office of CSG is to foster intergovernmental cooperation through the promotion of regional, as well as individual, state responses to common issues and challenges.

\section{Public Involvement in Radioactive Waste Management Decisions}

This report was prepared with the support of the U.S. Department of Energy, Cooperative Agreement No. DE-FC01-94RW00286. However, any opinions, findings, conclusions or recommendations expressed herein are those of the author(s) and do not necessarily reflect the views of DOE.

The purpose of the agreement, and reports issued pursuant to it, is to identify and analyze regional issues pertaining to the transportation of high-level radioactive waste and to inform Midwestern state officials with respect to technical issues and regulatory concerns related to waste transportation.

In addition to publishing reports related to the transportation of high-level radioactive waste, the Midwestern Office of the CSG has compiled a reference library on radioactive waste transportation. All materials are available by loan. For more information, contact CSG-MW at 708/810-(2210.

\section{Prepared by:}

Carol Ann Kania, Research Assistant and

Lisa R. Sattler, Policy Analyst

Midwestern Office

The Council of State Governments

641 E. Butterfield Road, Suite 401

Lombard, IL 60148-5651

(708) 810-0210

FAX (708) 810-0145 


\section{Table of Contents}

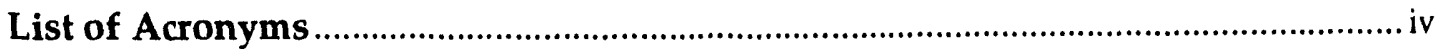

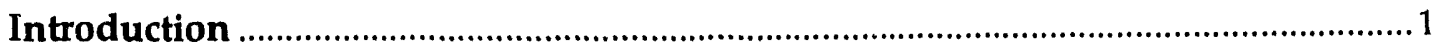

Public Perceptions: Attitudes, Trust, and Theory ……....................................................

Risk Perception ......................................................................................................... 2

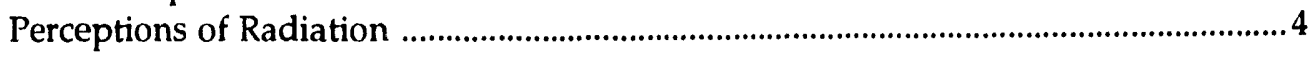

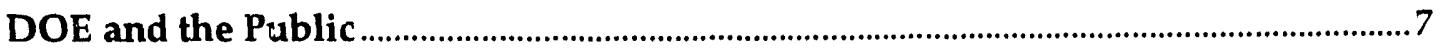

Defense Programs ......................................................................................................

Civilian Radioactive Waste Management Program ...........................................................

Repository Siting ................................................................................................

Public opinion in Nevada ..................................................................... 10

DOE outreach ........................................................................................ 11

Monitored Retrievable Storage Facility …………….........................................12

Transportation ...................................................................................................13

Other Efforts to Improve Public Participation .................................................................. 14

Midwestern Radioactive Waste Management Histories ..................................... 15

Repository Siting in the Midwest ........................................................................... 15

Spent Fuel Storage Facilities ........................................................................................ 17

Palisades (Covert, Michigan) .........................................................................18

Prairie Island (Welch, Minnesota) .................................................................... 19

Point Beach (Two Creeks, Wisconsin) ............................................................20

Monitored Retrievable Storage (MRS) Facility ............................................................. 21

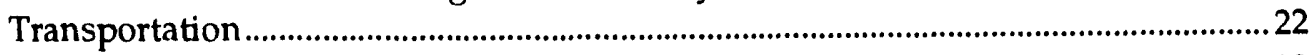

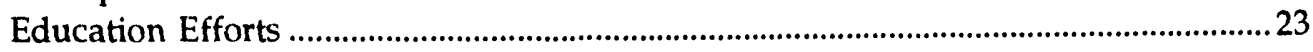

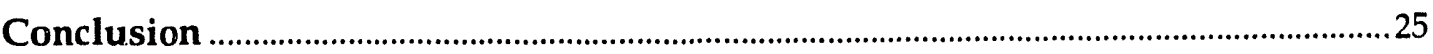

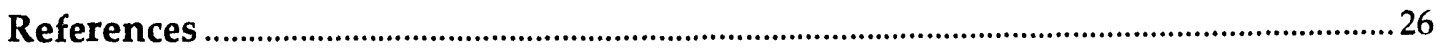

Tables

1. Results of a 1991 USCEA / Gallup Poll .......................................................................

2. Sources of Information about Radiation ..................................................................6

3. Media Coverage of Nuclear Safety (1970-1983) .......................................................6

4. 1991 Nevada Telephone Survey Results: Who do Nevadans Trust? ..................... 10

5. DOE Transportation External Coordination Working

Group Member Organizations .14

Figures

1. Factors for Locating Hazards .............................................................................

2. Route of Three Mile Island Spent Fuel Shipments ...............................................2 


\section{List of Acronyms}

$\begin{array}{ll}\text { AEC } & \text { Atomic Energy Commission } \\ \text { ANEC } & \text { American Nuclear Energy Council } \\ \text { CANS } & \text { Coalition Against Nuclear Storage } \\ \text { CSG-MW } & \text { Council of State Governments, Midwestern Office } \\ \text { DOE } & \text { U.S. Department of Energy } \\ \text { DOT } & \text { U.S. Department of Transportation } \\ \text { EPA } & \text { U.S. Environmental Protection Agency } \\ \text { ERDA } & \text { Energy Research and Development Administration } \\ \text { FBI } & \text { Federal Bureau of Investigation } \\ \text { FCR } & \text { Full-core reserve } \\ \text { GAO } & \text { General Accounting Office } \\ \text { IDNS } & \text { Illinois Department of Nuclear Safety } \\ \text { ISFSI } & \text { Independent Spent Fuel Storage Installation } \\ \text { LLW } & \text { Low-Level Waste } \\ \text { MEQB } & \text { Minnesota Environmental Quality Board } \\ \text { MPUC } & \text { Minnesota Public Utilities Commission } \\ \text { mrem } & \text { millirem } \\ \text { MRS } & \text { Monitored Retrievable Storage } \\ \text { NAC } & \text { Nuclear Assurance Corporation } \\ \text { NCSL } & \text { National Conference of State Legislatures } \\ \text { NRC } & \text { U.S. Nuclear Regulatory Commission } \\ \text { NSP } & \text { Northern States Power } \\ \text { NWN } & \text { Nuclear Waste News } \\ \text { NWPA } & \text { Nuclear Waste Policy Act } \\ \text { NWPAA } & \text { Nuclear Waste Policy Act Amendments } \\ \text { NWPO } & \text { Nuclear Waste Project Office } \\ \text { NWTRB } & \text { Nuclear Waste Technical Review Board } \\ \text { OCRWM } & \text { Office of Civilian Radioactive Waste Management } \\ \text { ONWN } & \text { Office of the Nuclear Waste Negotiator } \\ \text { ORMUG } & \text { Ohio Radioactive Materials Users Group } \\ \text { PSCW } & \text { Public Service Commission of Wisconsin } \\ \text { rem } & \text { roentgen equivalent man } \\ \text { SEAB } & \text { Secretary of Energy Advisory Board } \\ \text { SSSRC } & \text { Southwestern Social Science Research Center } \\ \text { TCG } & \text { Transportation Coordination Group } \\ \text { TEC } & \text { Transportation External Coordination } \\ \text { USCEA } & \text { U.S. Council for Energy Awareness } \\ \text { WCUB } & \text { Wisconsin Citizens Utilities Board } \\ \text { WEPCo } & \text { Wisconsin Electric Power Company } \\ & \end{array}$




\section{Introduction}

On December 7, 1993, the U.S. Department of Energy (DOE) revealed that almost 20 percent of the 1,051 nuclear tests conducted by this country since 1945 were done in secret, a figure twice as high as previously known. The department later disclosed that hundreds of Americans, many without their knowledge, were subjected to radiation tests, some of which included ingesting plutonium (Watson et al. 1993). These revelations marked the emergence of a new trend toward openness at DOE, as the department began to review and release 32 million previously classified documents. "We were shrouded and clouded in an atmosphere of secrecy," said Secretary of Energy Hazel O'Leary, "Ia]nd I would take it a step further: I would call it repression" (Cushman 1993).

Despite this new policy of openness, some environmental groups, hoping for more detailed information on the nuclear weapons program, were not satisfied with the amount of information disclosed (Cushman 1993). Clearly, then, while DOE adapts to the post-Cold War era through document declassification and a more open attitude toward the public, many members of the public will continue to be skeptical of the department's efforts in all aspects of nuclear materials management.

The safe, permanent disposal of spent nuclear fuel has been a concern ever since electricity was first generated at a commercial nuclear reactor near Shippingport, Pennsylvania, in 1957. Not until January 7, 1983, however, when the Nuclear Waste Policy Act (NWPA) was signed into law, did the nation have a comprehensive policy for disposing of spent fuel. The NWPA commits the federal government to solving the waste disposal problem and provides a statutory framework for the step-bystep development of a radioactive waste management program.

According to the original program schedule, the first repository was to open in 1998 with a second repository planned for 2006. ' Subsequent changes, including the 1987 Nuclear Waste Policy Amendments Act (NWPAA) and the Secretary of Energy's 1989 program reassessment, redefined the scope and pace of the program. Currently, DOE hopes to open a repository in 2010. The department had also planned to open a temporary storage facility in 1998 , but now that appears unlikely. The department also needs to develop a safe and efficient system for transporting radioactive waste to support its storage and disposal functions.

Current repository siting efforts focus on Yucca Mountain, Nevada, where DOE's Office of Civilian Radioactive Waste Management (OCRWM) is conducting exploratory studies to determine if the site is suitable. ${ }^{2}$ The state of Nevada has resisted these efforts: it has denied permits, brought suit against DOE, and publicly denounced the federal government's decision to study Yucca Mountain. The state's opposition reflects public opinion in Nevada, and has considerably slowed DOE's progress in studying the site. The Yucca Mountain controversy demonstrates the importance of understanding public attitudes and their potential influence as DOE develops a program to manage radioactive waste. The strength and nature of Nevada's opposition - its ability to thwart if not outright derail DOE's activities - indicate a need to develop alternative methods for making decisions that affect the public.

This report analyzes public participation as a key component of this openness, one that provides a means of garnering acceptance of, or reducing public opposition to, DOE's radioactive waste

'Although newspapers often use the term "dump," this report will use the word "repository," except when quoting, to make a distinction between a controlled, scientifically engineered site and uncontrolled, unsafe, or illegal disposal.

2Yucca Mountain has not been chosen to host the national nuclear waste repository. The site has unly been selected for characterization to determine if it is suitable to be a repository. 
management activities, including facility siting and transportation. The first section, Public Perceptions: Attitudes, Trust, and Theory, reviews the risk-perception literature to identify how the public perceives the risks associated with radioactivity.

DOE and the Public discusses DOE's low level of credibility among the general public as the product, in part, of the department's past actions. This section looks at the three components of the radioactive waste management program - disposal, storage, and transportation - and the different ways DOE has approached the problem of public confidence in each case.

Midwestern Radioactive Waste Management Histories focuses on selected Midwestern facility-siting and transportation activities involving radioactive materials. The section also discusses how DOE and other principal participants have attempted to involve the public in such projects as the construction of independent spent-fuel storage installations (e.g., at nuclear plants in Michigan, Minnesota, and Wisconsin), the siting of an interim storage facility (North Dakota, Minnesota, and lowa), and transportation (Three Mile Island shipments).

Nuclear scientists and engineers can solve technical problems; public opposition, though, may pose an insurmountable obstacle to the development of a system for managing radioactive waste. Nevertheless, work done now to increase understanding of public concerns may facilitate the process. This discussion will illuminate the public's concerns about radioactive waste management and the reasons behind those concerns.

\title{
Public Perceptions: Attitudes, Trust, and Theory
}

\begin{abstract}
Although it's hardly news that the public is opposed to the siting of radioactive waste dumps, what is startling is the depth of public fear and revulsion. The public's visceral horror of all things nuclear has never been adequately understood by the government or the nuclear power industry, which have tended to dismiss such concerns as irrational or rooted in misperception and misinformation (Flynn et al. 1992, 43).
\end{abstract}

Public perception of nuclear power is clouded by the technology's awesome beginnings. The force contained in the fission of atoms made its public debut in the bombs that annihilated two cities. No other technology began in such a "backwards" way, demonstrating its most destructive capability before being harnessed for more everyday applications (Carter 1987, 42).

Of course, today nuclear technologies play a prominent role in the energy and health-care industries. Nuclear power plants produce over 20 percent of the electricity consumed in the U.S. (USCEA 1993, 5). The diagnosis and treatment of cancer and a host of other diseases rely heavily upon the use of radioactive isotopes. The more benign uses of nuclear technology, however, have not been able to erase the association between "nuclear" and "weapons." As Kirk Smith noted, "Nuclear energy was conceived in secrecy, born in war, and first revealed to the world in horror. No matter how much proponents try to separate the peaceful from the weapons atom, the connection is firmly embedded in the minds of the public" (quoted in Slovic et al. 1991, 11).

\section{Risk Perception}

To understand the public's "visceral horror of all things nuclear," one must start with a concept of risk - an idea that scientists and lay people define very differently. On the one hand, scientists assess risk based on the probability of events and their consequences. In this way, risks can be expressed in measured terms, such as dollars or dosages, and compared to one another. 
Lay people, on the other hand, do not so much assess risks as perceive them. Perceived risks have an unconscious element, which is often hard to quantify. Individuals perceive risks through not only personal experience but also learned associations, intricately constructed ideas, unarticulated beliefs or feelings, and deep emotions. The strength of these forces is hard to calculate simply because they differ from person to person.

In perceiving risks, people use a variety of mental strategies, called heuristics, to "reduce the complex tasks of assessing probabilities and predicting values to simpler judgmental operations" (Tversky and Kahneman 1986,38). According to one strategy, availability, an accident will be regarded as more "serious" if people can easily call examples to mind. Understandably, strong images of recent or even distant events can influence the availability heuristic and distort perceptions of risk (Tversky and Kahneman 1986, 47-8). Airplane crashes, for example, are very rare considering the number of flights that cross the world every day, yet people remember them easily and vividly. Similarly, people can recall accidents involving nuclear power, such as Three Mile Island and Chernobyl, ${ }^{3}$ because of extensive news coverage both during the events themselves and on subsequent anniversaries.

Along with availability, risks are judged on the basis of familiarity. Hazards from everyday activities may be overlooked because they occur in comfortable, familiar systems. Unusual, dramatic events, however, cause alarm because they do not occur in a common context (Tversky and Kahneman 9186, 39). For instance, people may live in fear of plane crashes or nuclear power plants, yet they often remain indifferent to dangers closer to home, such as highway travel, smoking, or fat consumption.

Another strategy, called representativeness, involves the tendency to regard a single phenomenon or event as representative of an entire class (Tversky and Kahneman 1986, 39). This strategy explains why nuclear weapons, with their imagery of death and destruction, have come to characterize all of nuclear technology in the public's mind. Weapons production and commercial nuclear power are produced by different institutions for different purposes, yet nuclear power, nuclear medicine, and nuclear waste disposal have been tainted in people's minds with the images and ideas of weaponry.

H.W. Lewis, in his book Technological Risk, describes the elements affecting an individual's perception of risk in the form of questions:

- Is the risk voluntarily assumed or imposed by outside forces?

- Is the risk familiar or unfamiliar?

- Does the risk lead to immediate harm or harm far in the future?

- Is the risk expressed in terms of benefits or losses? (30).

A process known as factor analysis can aggregate the answers to these questions into a measurement of how risky an event or activity is perceived to be. Factor analysis condenses the range of attributes of risk into two factors - unknown risk and dread risk (Figure 1). This model makes the concept of risk perception quite simple. A risk that is voluntary and familiar to the individual, such as smoking, is commonly perceived as less risky than one that is unfamiliar and over which the individual has no control. Similarly, risks that bring harm far in the future are often easier to accept than those whose effects are immediate. Expressing risks in terms of benefits rather than losses also helps to make them more palatable. In calling for tax increases, for example, legislators tend to highlight the advantages to taxpayers - better schools and roads - over the disadvantage of having to pay higher taxes.

'The type of reactor involved in the Chernobyl accident is not used in the U.S. 


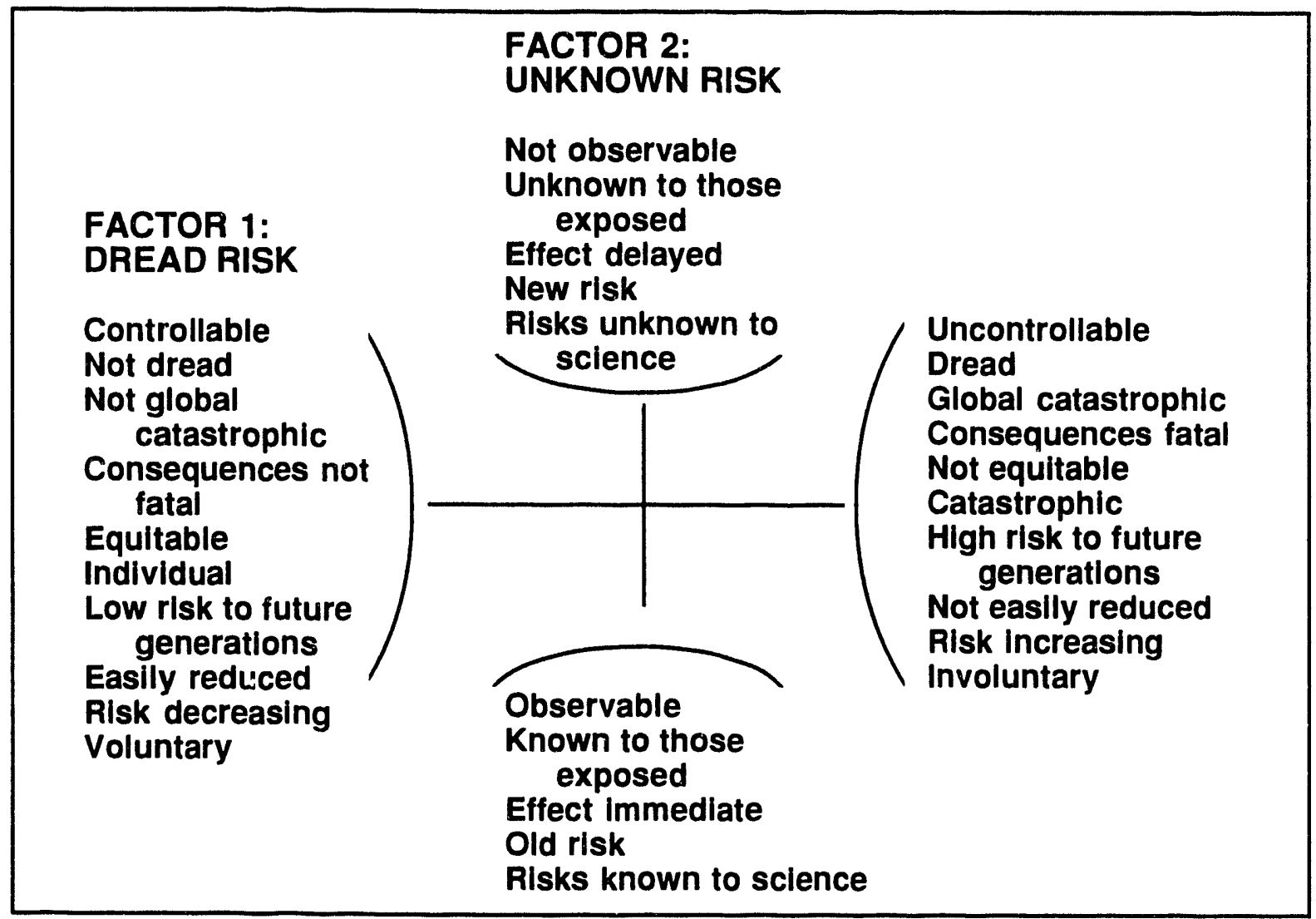

Figure 1. Factors for Locating Hazards.

Source: DOE 1993a, 53.

\section{Perceptions of Radiation}

Considering the attributes of radiation, it is no wonder such a large segment of the population harbors a deep-seated fear of radiation and nuclear technologies in general. At the most basic level, although "radiation" is a familiar term that evokes a number of mental images, most people do not understand the scientific concept of electromagnetic radiation. The abstract, even esoteric nature of nuclear fission exacerbates this problem: people cannot witness fission in the same way they can, say, combustion. As a result, nuclear technologies and their byproducts are unfamiliar to most people.

Second, with few exceptions (most notably in the health care industry), exposure to radiation, whether real or perceived, is involuntary. The effects of exposure - like radioactivity itself - are unseen. That is, they occur internally, on a cellular scale. Further, radioactive materials seem to the public to be almost unimaginably powerful and long-lived: spent fuel and high-level radioactive waste, for example, contain elements with half-lives of hundreds of thousands or even millions of years.

With all these attributes, radiation and nuclear technology engender a basic "dread" in the public. Even in the early days of the nuclear age, people were uncomfortable with the technology. After Brookhaven National Laboratory opened in New York, stories abounded of pilots who refused to fly over the laboratory, of a woman who wondered if radiation from the facility would make her pregnant, and of local residents blaming "weird gases" for illnesses (Weart 1988, 177). Public opinion surveys supported this anecdotal evidence. During the Atoms for Peace Program, when many people were still optimistic regarding civilian nuclear power, surveys showed a "hard-core fourth" of the population was fearful of nuclear power, and two-thirds mentioned destructive images immediately in response to the word "atom" (Weart 1988, 178). 
According to recent surveys, these sentiments persist to this day. In 1991, the U.S. Council for Energy Awareness (USCEA), the public relations arm of the nuclear industry, commissioned a study from the Gallup Organization to learn about the public's awareness, understanding, and perception of radiation. Respondents were asked, "When you hear the word 'radiation,' what are some of the things that come to mind?" Sixty percent of the respondents made negative associations, including bodily harm, cancer, death, destruction, nuclear war, and fallout (Table 1) (Bisconti and Livingston 1992, 3).

A 1991 study by Decision Research for the Nevada Nuclear Waste Project Office (NWPO), the state's independent body charged with reviewing Yucca Mountain activities, found similar results. In four national telephone surveys conducted between April 1988 and January 1990, 3,334 people were asked to say the first six thoughts or images that came to mind when they heard the term "underground nuclear waste storage facility." Out of 10,000 responses, 60 percent were related to negative consequences or concepts, reflected in terms such as "dangerous," "death," "environmental damage," and "scary" (Slovic et al. 1991, 10). The survey authors concluded that these images "reveal ... pervasive feelings of dread, revulsion, and anger - the raw materials of stigmatization and political opposition" (Slovic et al. 1991, 11).

Statistics and expert opinions do not support the public's fears. Nuclear technology is not a major or even statistically significant cause of death in the U.S. ${ }^{4}$ Many experts are stymied by what they consider public misperceptions. For example, Sir John Hill, former chairman of the United Kingdom's Atomic Energy Authority, said that he had "never come across an industry where the public perception of the problems is so totally different from the problems as seen by those of us in the industry" (Carter 1987, 9).

The gap between public opinion and expert assessment reflects the public's lack of confidence in the scientific community. After World War II, the public was willing to trust scientists, who were seen as uniquely qualified to make decisions about nuclear technology. Events during the 1950s, though, indicated that scientists still had questions about the safety of nuclear technology. Despite assurances that the radiation from nuclear weapons testing was not harmful, independent surveys concluded that there would be a small but not insignificant increase in exposure for every person on earth (Carter 1987,78). This contradictory message coming from the experts was sufficient to shake public confidence in the whole scientific community. As one nuclear historian observed, "The highly visible debate over fallout led some to question generally the authority of experts" (Balogh 1991, 169). Even today, the fact that there are scientists with serious doubts about nuclear power overshadows the fact that most agree it is safe.

\begin{tabular}{|c|c|}
\hline \multicolumn{2}{|c|}{$\begin{array}{c}\text { Table 1. Results of a } 1991 \\
\text { USCEA/Gallup Poll }\end{array}$} \\
\hline \multicolumn{2}{|c|}{$\begin{array}{l}\text { Respondents were asked, "When you } \\
\text { hear the word 'radiation,' what are some } \\
\text { things that come to mind?" }\end{array}$} \\
\hline Associations & Percent \\
\hline Negative physical effects & 36 \\
\hline cancer & 17 \\
\hline death & 12 \\
\hline sickness & 9 \\
\hline burns & 5 \\
\hline radiation poison & 2 \\
\hline Medical benefits & 33 \\
\hline X-rays & 19 \\
\hline cancer treatment & 11 \\
\hline other treatment & 6 \\
\hline Destruction & 21 \\
\hline dangerous & 11 \\
\hline waste/contamination & 5 \\
\hline destruction & 4 \\
\hline accidents & 4 \\
\hline War/Aggression & 21 \\
\hline bombs & 11 \\
\hline nuclear war & 5 \\
\hline weapons & 3 \\
\hline fallout & 2 \\
\hline Electricity/energy & 18 \\
\hline nuclear power & 15 \\
\hline energy & 4 \\
\hline Natural radiation & 8 \\
\hline sun & 6 \\
\hline radon & 2 \\
\hline
\end{tabular}

Source: Bisconti and Livingston 1992, 3.

${ }^{4}$ Despite this fact, in 1987, a group of college students and members of the League of Women Voters ranked nuclear power first on a list of risky activities, ahead of statistically more dangerous activities as smoking, driving, and handgun use (Slovic 1987, 281). 
Suspicious of the scientific community, the public increasingly turned to the media for information on nuclear technology (Table 2). Because journalists work under space and time constraints, often they do not have time to learn about the issues they cover. Furthermore, stories on complex issues such as radioactive waste disposal are usually condensed into a column and a headline or a 3-minute television or radio segment and a sound bite (Mandra 1992). Mainstream journalists also play up conflict or "human interest" to make a story more interesting.

Moreover, for the sake of fairness, reporters often give equal time to both sides of the debate, thereby creating the impression that scientists are evenly split over the question of nuclear safety. According to one study, journalists also tend to be antinuclear and to seek out experts with the same view. As a result, media coverage of nuclear issues tends to be biased (Table 3) (Rothman and Lichter 1987, 391). Further, images from popular culture - from the Incredible Hulk and The Simpsons to China Syndrome and Silkwood - have reinforced the public's wariness, if not outright fear, of nuclear technologies and the institutions that regulate them.

Environmental groups also play a large part in shaping public opinion on nuclear issues. From international groups such as Greenpeace

\begin{tabular}{|lc|}
\hline \multicolumn{2}{|c|}{$\begin{array}{c}\text { Table 2. Sources of Information } \\
\text { About Radiation }\end{array}$} \\
\hline Source & $\frac{\text { Percentage }}{86}$ \\
News Reporting & 86 \\
Science books or magazines & 64 \\
Dramatic episodes in movies or television & 61 \\
A doctor & 54 \\
School & 45 \\
A Dentist & 36 \\
Utility & 21 \\
Cartoon, comic books & 13 \\
Don't know & 4 \\
\hline
\end{tabular}

Source: Bisconti and Livingston 1993, 7. to small local groups that form to oppose interim storage of spent nuclear fuel, environmental organizations have the human and financial resources to stage highly visible campaigns. Many people consider environmental groups to be reliable sources of information because their goal is presumably to protect the earth and its inhabitants. Scientists and the nuclear industry, on the other hand, are often regarded as acting out of self-interest.

The antinuclear message that the public gets from the media and from environmental groups reinforces deep-seated fears of radiation. That is to say, the message largely confirms what people have come to believe and, by extension, what they expect to hear. Some proponents of nuclear power insist

Table 3. Media Coverage of Nuclear Safety (1970-1983)

\begin{tabular}{|c|c|c|c|}
\hline \multirow[t]{2}{*}{ Content } & \multicolumn{3}{|c|}{ Percentages } \\
\hline & NY Times & News mag. & TV \\
\hline \multicolumn{4}{|l|}{ Story slant: } \\
\hline pronuclear & 7 & 27 & 17 \\
\hline antinuclear & 10 & 46 & 42 \\
\hline neutral & 83 & 29 & 41 \\
\hline \multicolumn{4}{|l|}{ Safety judgment: } \\
\hline positive & 45 & 45 & 34 \\
\hline negative & 55 & 55 & 66 \\
\hline \multicolumn{4}{|l|}{ Expert sources cited: } \\
\hline pronuclear & 9 & 17 & 11 \\
\hline antinuclear & 7 & 40 & 62 \\
\hline neutral & 84 & 43 & 27 \\
\hline Number of stories: & 486 & 213 & 582 \\
\hline
\end{tabular}
that these beliefs will change if the government or the industry provides the public with the correct information. Many other experts, however, believe that one's understanding of nuclear power and one's feelings about it are often two separate things (Weart 1988, 366). James Flynn of Decision Research remarked that "opposition to nuclear-waste disposal plans is not due to ignorance of technical facts. It is, instead, based on a profound lack of trust in the scientific, governmental, and industrial managers of nuclear technologies" (1992). As one expert on risk communication observed, "All the empirical evidence in the world won't persuade a skeptical public if the message and the messenger are not credible" (NWN 1994).

Source: Rothman and Lichter 1987, 393. 


\section{DOE and the Public}

Many reports, task forces, and working groups studying the radioactive waste management program have noted the lack of public confidence in the Department of Energy (see, e.g., SEAB Task Force 1993, Flynn et al. 1991, Dantico et al. 1991). Some of these reports have observed that the problem of confidence stems, at least in part, from the public's negative reaction to all things nuclear. The Nuclear Waste Technical Review Board (NWTRB), for example, addressed the problem of public mistrust in its December 1992 report: it concluded that, "unless public perception about the risks associated with nuclear power and the waste it generates can be addressed, efforts to site a permanent repository for burying such waste will continue to meet with opposition" (NWTRB 1992, 43).

Yet DOE certainly shares part of the blame for the lack of public confidence. While much of the current discussion surrounding DOE's poor public image focuses on the activities of the Civilian Radioactive Waste Management Program, it is important to note that the public's low opinion of the department as a whole had already been established well before Congress passed the NWPA. The department's gross mismanagement of defense wastes laid the foundation for public mistrust, while events outside the department's control (e.g., the accident at Three Mile Island) solidified a widespread lack of public confidence in the federal government's ability to regulate nuclear technologies. ${ }^{5}$

\section{Defense Programs}

Secrecy surrounded DOE's defense programs and contributed to public mistrust. The manufacture of nuclear weapons produced a great deal of radioactive waste, yet because these programs were regarded as vital to national security, the public often could not get information on the hazards defense wastes posed to their communities. During the Cold War arms build-up, DOE's “war mentality" and national security interests may have justified these practices (SEAB Task Force 1993, 37). In promising to release formerly classified documents, DOE now seems to acknowledge that these practices are no longer necessary.

Widely publicized incidents at DOE's weapons production plants stand as signals in the public's mind of DOE's numerous lapses in the area of waste management. Perhaps the most extensive case of mismanagement occurred at DOE's Hanford facility in Washington. Hanford produced plutonium for the nation's defense program and, in the process, generated enormous quantities of radioactive waste. Liquid high-level waste was placed in underground tanks for storage, while intermediate-level waste was discharged into the soil and solid low-level radioactive wastes were buried in trenches.

In June 1973, a leak of 115,000 gallons of liquid high-level waste from one of the storage tanks was discovered. The leak had gone unnoticed for 51 days, with more than 2,000 gallons escaping each day. Monitoring data collected during this time showed that something was wrong, but the workers who collected the data were not expected to interpret them. The person charged with that responsibility left the data on his desk, unread, for six weeks.

Although most of the waste was absorbed near the tanks, the leaks led to lawsuits, which demanded that Hanford stop reprocessing high-level wastes (Carter 1987, 72). Publicity surrounding the lawsuits increased public awareness of DOE's problems with waste management. The public continues to be concerned about the Hanford facility. Stories of oysters contaminated by radioactive waste discharged into the Columbia River and a high-level waste tank "burping" periodically to release

\footnotetext{
5Although the accident at Three Mile Island occurred under the jurisdiction of the U.S. Nuclear Regulatory Commission, its legacy has strongly influenced public attitudes towards all federal bodies charged with regulating nuclear technologies.
} 
pent up flammable gases are now part of the lore concerning DOE's failure to manage radioactive waste properly at Hanford (Carter 1987, 52-3; NWN 1993a).

Like Hanford, DOE's Rocky Flats Plant near Denver is well known because of mismanagement. During the 1980s, the State of Colorado and the U.S. Environmental Protection Agency (EPA) fought DOE for greater control of the facility. In 1989, the Federal Bureau of Investigation raided Rocky Flats because of allegations that its operators illegally stored and burned hazardous and radioactive wastes. Governor Roy Romer threatened to shut the plant down if DOE did not immediately release information on the potential health effects of these practices. Although it was unclear whether the governor had the authority to carry out his threat, the Secretary of Energy cooperated and stopped manufacturing plutonium at the site. In 1991, the state and DOE reached an agreement to clean up the site, monitor the environment, allow state ofticial and independent experts into the site, and form a citizens advisory committee (Wells 1993, 12-13).

In 1992, a grand jury tried to indict DOE officials and executives of Rockwell International, the former contractor of the Hanford facility, for violating environmental laws. Instead, Rockwell agreed to pay $\$ 18.5$ million for hazardous waste management violations (Wells 1993, 13). The former grand jurors continue to press their case and, although they have been under investigation for violation of secrecy laws, they hope to testify before Congress (Watson et al. 1993, 18).

Hanford and Rocky Flats are not the only DOE defense plants at which environmental and public safety were compromised by poor waste management practices. Because of the widespread media attention these two facilities received, though, the names Hanford and Rocky Flats exemplify for many people DOE's mismanagement of radioactive wastes. As the nuclear power industry learned from its experience with Three Mile Island, such strong associations are very difficult, if not impossible, to efface. ${ }^{\circ}$

\section{Civilian Radioactive Waste Management Program}

DOE's reputation for being secretive and, at worst, indifferent to public health and safety carried over from its weapons production activities into the department's other programs. In 1991, the Secretary of Energy appointed a task force to study the department's problems with public trust and confidence in the Civilian Radioactive Waste Management Program. In its final report, the Secretary of Energy Advisory Board (SEAB) Task Force on Radioactive Waste Management noted that "the legacy of distrust created by the Department's long history and culture will continue for a long time to color public reaction to its radioactive waste management efforts" (SEAB Task Force 1993, 45). The Task Force also round that, while DOE acknowledged the importance of building public trust and confidence, it failed to take any meaningful actions to accomplish this goal. Based on its findings, the Task Force sternly concluded that DOE's "decision making behavior will have to fundamentally change" (SEAB Task Force $1993,38)$.

The components of DOE's Civilian Radioactive Waste Management Program demonstrate three different ways DOE has approached the problem of public confidence. To site the repository and fulfill its Congressional directive, DOE tried to ignore the public outcry against the characterization of

\footnotetext{
-The accident at Three Mile lsland in 1979 caused no deaths and is expected tu produce few latent illnesses. Yet, taking into account not only the financial but societal effects, it is arguably the most custly accident in U.S history. The accident devastated the plant's operating utility, inspired strict and expensive regulations on the nuclear industry (which, in turn, reduced the demand for new nuclear plants), and increased opposition to nuclear power (Slovic 1990, 82-3). The accident also demonstrated that trust is quickly lost and slowly regained, especially in low-probability, high-consequence areas such as nuclear power, where the public interprets a single event as a demonstration of extreme risk (Slovic 1991, 6-7).
} 
Yucca Mountain. As a result of the state's vehement opposition, DOE's progress in studying the site has been slow. Rather than relive this same experience in siting a temporary storage facility, DOE deferred most of its own activities to give the independent Nuclear Waste Negotiator time to locate a voluntary host for the facility. Yet even this voluntary approach has met with little success. DOE's development of a safe and publicly acceptable transportation system, though, stand out as one of the department's most successful efforts to cultivate trust and confidence by involving the public in decision making.

\section{Repository Siting}

DOE's problems with public confidence have seriously hindered the process of repository siting. These problems can be traced to DOE's former practice of making decisions based on a strategy of "decide-announce-defend." The department generally based its waste management decisions solely on the advice of technical experts, announced these decisions to the public, and then rigorously defended them (Power et al. 1993, 1-2). DOE did not involve the public in the decision-making process in any meaningful way. Similarly, state, local, and tribal officials - who would have the responsibility for responding to emergencies - were not consulted and their concerns were not heard. External parties had very little recourse to challenge DOE's decisions, as federal officials were reluctant to reopen decisions once they were made (Power et al. 1993, 2).

Such was the case with DOE's first attempts to site a national repository for nuclear waste. Preliminary studies in the early 1970s of a site in Kansas and in the mid-1980s of sites in Wisconsin, Michigan, and other states met with staunch opposition from state residents and government officials. Opposition to repository siting was so strong that DOE eventually abandoned all site characterization activities in these states (see the section on Midwestern Radioactive Waste Management Histories for more information).

In 1987, Congress attempted to streamline the repository-siting process in the NWPAA by designating Yucca Mountain as the only candidate for site characterization. ${ }^{7}$ DOE maintains that Yucca Mountain was chosen for characterization because of its geology, arid climate, and sparse population and vegetation. Yet opponents contend that Congress selected Yucca Mountain for purely political reasons. As evidence, they point to the fact that the NWPA was amended when three of the four members of Nevada's congressional delegation were in their first term of office, whereas Washington and Texas, the two other states under consideration, had powerful representation in Congress (Church $1990,22){ }^{8}$

In 1988, political action against site characterization of Yucca Mountain became organized. The Nevada Legislature passed a bill prohibiting the storage of radioactive waste in the state, along with two resolutions declaring opposition to repository siting. The state also refused to issue DOE the permits necessary to study the site - a surface disturbance permit to dig holes, a permit to use chemical tracers in the ground water, and a water rights permit.

Nevada brought suit against DOE, charging that the state's legislative resolutions constituted a veto under the NWPA." The state also contended that DOE should have stopped investigating Yucca

TPrior to the passage of the NWPA, three sites were under study: Deaf Smith County in Texas, Hanford in Washington, and Yucca Mountain in Nevada. In 1986, DOE selected these three from an original list of nine potential sites (Carter 1987, 401). Washington.

"Jim Wright, the Speaker of the House, was from Texas; House Majority Leader Tom Foley was from

"Under the NWTA as amended, a state chosen to host the repository may veto the decision. Cungress has 90 days to overturn the veto. 
Mountain because geologic conditions should have disqualified the site (NWTRB 1991, 30). In 1990; DOE filed suit in the U.S. District Court over Nevada's refusal to issue the necessary permits. The department argued that, because Yucca Mountain was only under study and had not been chosen to host the repository, the state's veto was not valid (Church 1990, 23-4). In September 1991, the Ninth District Court ruled in favor of DOE. The state has now issued all permits for site characterization (Gomberg 1993).

Public opinion in Nevada. In 1993, Governor Robert Miller commented that much of the public opposition to the Yucca Mountain project "stems from basic mistrust of the Department of Energy, ... a mistrust that DOE has acquired the old-fashioned way: They've earned it" (NWN 1993b). Polls have tended to support this claim. A 1991 survey by Decision Research for the NWPO indicated that DOE was one of the least trusted government entities, in the opinion of Nevada residents (Table 4). Out of 10 institutions, DOE ranked 9th, ahead of only the U.S. Nuclear Regulatory Commission (NRC). In contrast, the Nevada governor and the state legislature ranked first and second, with almost one-fourth of the people surveyed indicating "complete trust" in the governor (Flynn et al. 1991, Table B-1). An earlier study by Arizona State University (1988-1989) found similar results, concluding that, as the respondents' trust in state and local officials grew, so did their perception of the risks of the repository. In other words, the survey authors concluded, state opposition to Yucca Mountain exacerbated the respondents' perception of risk (Dantico et al. 1991).

\begin{tabular}{|lr|}
\hline \multicolumn{2}{|c|}{ Table 4. 1991 Nevada Telephone } \\
Survey: Who do Nevadans Trust? \\
\hline Government Body & Mean \\
\hline Nevada Governor & 7.0 \\
Nevada Legislature & 6.4 \\
U.S. Congress & 4.5 \\
DOE & 4.3 \\
NRC & 3.9 \\
\hline
\end{tabular}

aOn a scale of 1 to 10 , with 10 indicating complete trust.

Source: Flynn et al., 1991, 16.

In an attempt to improve public opinion in the state, the nuclear industry inadvertently fueled public opposition. In 1991, the American Nuclear Energy Council (ANEC), an industry organization, mounted a multi-million dollar advertising campaign to educate Nevadans and correct misinformation. With the help of a Las Vegas advertising agency and a former local TV sportscaster, the ANEC ads emphasized safety and the virtues of nuclear power. Soon after the campaign began, Decision Research measured the effectiveness of the ads. Thirty-two percent of those surveyed said the ads made them less supportive of the repository, and 75 percent said they still opposed the project - the same percentage as before the campaign. Sixty-five percent of respondents found the ads unbelievable or insulting (Flynn 1992).

The campaign failed, said an associate at Decision Research, because Nevadans "did not trust the experts who told them it was safe." ANEC documents leaked to the media by an antinuclear group revealed that the purpose of the campaign was to sway opinion towards the repository and buy time for legislators to negotiate benefits. But perhaps the most devastating critique came from local disk jockeys and businesses, who satirized the campaign in their own ads. One restaurant even put its tomatoes through the same tests as nuclear waste casks shown in the ANEC ads (Flynn 1992).

Nonetheless, despite the results of the aforementioned surveys, evidence suggests that some Nevadans may be willing to accept a repository at Yucca Mountain. Some local residents say a repository may help business. ${ }^{10}$ A town just east of Death Valley greets tourists with a sign that says, "Welcome to Amargosa Valley, Home of Yucca Mountain." In another indication of support, the Nevada Nuclear Waste Study Committee directed 5,000 postcards to the Nevada capitol promoting scientific investigations. After hearing from residents who support a negotiated agreement, some

"Perhaps this acceptance of the site study comes from the fact that the area has lived with the Nevada Test Site since 1951 (Allen 1993). 
Nevada legislators expressed interest in seeking financial benefits for hosting the repository. This apparent shift in attitude was attributed to concern over the loss of jobs at the Nevada Test Site (NCSL 1993a, 9).

Polls continue their battle to assess public sentiment in the state. A February 1993 poll commissioned by ANEC revealed that 82 percent of the 750 people questioned felt that the legislature should begin benefits discussions, although two other surveys conducted at the same time showed that a $m$. jority of Nevadans continued to oppose the repository (NWN 1993d). According to a 1993 study by the University of Nevada-Las Vegas, slightly over half of the 718 respondents surveyed either strongly supported ( 8.5 percent) or supported ( 46.5 percent) the current study of Yucca Mountain. The survey also concluded, however, that the public has simply resigned itself to the situation. Sixty-three percent of respondents did not believe the state could stop the study of Yucca Mountain, and 71 percent said the repository would be built in Nevada regardless of opposition (SSSRC 1993, 1).

DOE outreach activities. In an effort to quell public fears about the Yucca Mountain project, DOE has stepped up its public outreach activities in Nevada. One of the most visible programs is the Yucca Mountain tour program. Tours of the site are open to any U.S. citizen over the age of 14 . DOE even has a tour program designed specifically to educate students about the concept of a high-level nuclear waste repository, increase their awareness of energy and environmental issues, communicate basic concepts of earth science and geology, and provide information about careers in science and engineering. Preceding the tour, project scientists and engineers meet with students and teachers, with presentations tailored to meet the needs of specific age groups.

Other education initiatives include the Nevada Science Project, a teacher-run program designed to help teachers develop programs to teach scientific, technological, and social issues, and DOE's secondary level textbook series, Science, Society, and America's Nuclear Waste (Gilbert and Robinson 1992, 1813; Scull 1992, 1807). DOE is promoting this curriculum series through teachers' teleconferences, which also highlight current events and issues in radioactive waste management (NWN 1993c).

As valuable as public information and education is for getting information to interested parties, it is largely a one-way process. To ensure a two-way system of communication, DOE, as directed by the NWPAA, provides financial assistance to affected state and local governments to study the potential impacts a repository would have on the area and to monitor site characterization activities (NWPA $\$ 116(\mathrm{c}))$. The State of Nevada, the largest of the affected governments, receives $\$ 5.5$ million each year to fund the Nevada Nuclear Waste Project Office (Strolin 1994). This state agency is responsible for oversight of DOE's site characterization activities and for carrying out Nevada's responsibilities under the NWPA. The office studies technical, environmental, socioeconomic, and transportation issues, and produces technical reports and public information materials (DOE 1992, 2).

The counties affected by site characterization activities are Churchill, Clark, Esmerelda, Eureka, Lander, Lincoln, Mineral, Nye, and White Pine Counties in Nevada and Inyo County in California (Strolin 1994). The counties use their NWPA funds $-\$ 7$ million for the entire group - to oversee the project, provide information on the project to local residents, and make sure the counties have input into DOE's decisions regarding site characterization. Eureka County, for example, hired an information officer, held public meetings, and developed a newsletter. The county plans to issue a socioeconomic report and an assessment of the need for a Geographic Information System, or a database to analyze geographic information (Eureka County Information Office 1993, 7).

DOE's outreach program is a step in the right direction in that it demonstrates the department's recognition that the public has a legitimate interest in the department's actions and that public trust and confidence are important to the success of the repository project. Yet public opposition in Nevada is so 
strong and so ingrained that outreach - no matter how open and comprehensive - may not have any effect on public opinion.

\section{Monitored Retrievable Storage Facility}

In contrast to repository siting, the siting process for the Monitored Retrievable Storage (MRS) facility was to be a model of public involvement. The Office of the Nuclear Waste Negotiator (ONWN), created in the NWPAA, is an independent agency charged with finding a voluntary host for the permanent or temporary storage of spent nuclear fuel. Volunteers are under no obligation to accept the storage facility, and can withdraw from the siting process at any time. This "no-risk" process reflects the eight operating principles of the ONWN:

- the process must be truly voluntary

- requests for information and preliminary discussions are not seen as a commitment

- all dialogues can be stopped at the will of the host

- all discussions begin with evaluations of health, safety, and environmental issues

- there are no irrelevant issues

- the host is entitled to compensation for helping to solve a national problem

- the process must consider the all views

- the process is only successful if all stakeholders participate (Leroy 1993, 1-3).

DOE offered grants to states, tribes, and local governments interested in studying the feasibility of hosting a temporary storage facility. The feasibility grants were available in three different amounts to fund activities under three "phases" or levels of increasing interest. The first two phases consisted mainly of informing local residents of the project and assessing whether there was any interest in hosting the facility and, if so, whether any local sites would be appropriate. Applicants could enter the third level of the process only if they were willing to demonstrate their interest in entering "credible formal discussions" over hosting the facility (CSG-MW 1994, 2.7). ${ }^{11}$ Furthermore, local governments were required to provide a letter from the state governor declaring his or her support for the proposal.

In practice, however, the voluntary siting process proved to be almost as difficult as siting the repository, largely because of public fears. Although the ONWN is independent of DOE, the funds for feasibility grants came from the department. Such a strong link between these agencies made it difficult for the public to distinguish between the two. In newspaper accounts of MRS-related activities, the grants were linked either to "DOE" or simply to "the federal government" (see, e.g., Omaha World-Herald 1993, Beeman 1993a, Greenberg 1993, 83).

The temporary nature of the MRS facility did not make the siting process easier. In fact, in many cases the public expressed fears that a temporary site would become permanent if DOE failed to construct a repository. In 1992, after blocking Fremont County's proposal to proceed with its feasibility assessment, Wyoming Governor Mike Sullivan said, "After five years and over a billion dollars in investment, and more billions to be spent, the permanent repository at Yucca Mountain, Nevada, is neither sited nor assured of its permanent status. Can we be paid enough or place enough trust to accept a permanent repository that was intended to be temporary? It is my belief that we cannot" (Nealey and Morris 1993, 1885-6).

"In 1993, Congress discontinued funding for the third grant phase at the request of Sen. Jeff Bingaman (DNM) (NCSL 1993c, 12). The State of New Mexico had repeatedly opposed the Mescalero Apache Indians' efforts to study the feasibility of hosting the MRS facility (New Mexico Governor's Office 1994). 
The number of Indian tribes applying for feasibility grants further complicated the ONWN's attempts to find a voluntary site for the MRS facility. Sixteen of the 21 grant applicants were Indian tribes, leading environmental groups and some tribes to accuse the government of "targeting" tribes as potential hosts (CSG-MW 1994, 2.6; South Dakota Argus Leader 1993). Despite DOE's assertions that the process was strictly voluntary, opponents charged the department with cultural insensitivity and "environmental racism," arguing, in effect, that Indian reservations are so economically destitute that tribes are incapable of turning down an opportunity to host the MRS facility.: Native American groups, however, insist that tribes should be allowed to make their own decisions about hosting an MRS facility.

DOE's own actions following the 1992 presidential election also hindered the efforts of the ONWN. In December, Secretary Watkins redirected the MRS program away from voluntary siting of a new facility in favor of utilizing existing DOE facilities for temporary storage. The ONWN responded to this announcement with anger and frustration over DOE's weak commitment to the voluntary process (NWN 1992a). The ONWN continues its search for a voluntary site and is working closely with two Native American tribes despite the fact that Congress eliminated funding for feasibility grants.

\section{Transportation}

Opposition to transportation under DOE's program is practically nonexistent, even in Nevada. Of the 10,000 responses to the Nevada telephone survey, for instance, only 38 specifically mentioned transportation (Slovic et al. 1991, 11). One reason for this apparent lack of concern is that local activities related to radioactive waste shipments have not yet begun. A less obvious but still important reason could be that over 1,200 shipments of spent fuel have crossed the country without a release of radiation or major injury (NRC 1992, 7). The apparent indifference towards transportation will certainly change, though, once shipments begin. According to OCRWM's 1991 Draft Mission Plan Amendment, "The transportation of radioactive waste may do more to bring radioactive waste disposal to widespread public attention than any other aspect of the Federal waste management program" (OCRWM 1991, 101).

Because the transportation system will be the last to come on line, DOE has been able to proceed relatively slowly with its development. DOE has used this situation to its advantage by establishing a number of avenues for involving stakeholders in policy making. To improve its communication with external parties, DOE entered into cooperative agreements with some of these groups. Cooperative agreements, which come in the form of financial assistance, are consensus a wards in which the objectives agreed upon reflect the mutual goals of DOE and the a wardee. Through ad visory committees, meetings, and publications, cooperative-agreement groups learn about DOE's waste management activities and identify, discuss, and work to resolve issues related to radioactive waste transportation. DOE currently has seven cooperative agreements related to transportation, including one that sponsors the activities of the Midwestern High-Level Radioactive Waste Committee (Teer 1993, 16). DOE also funds cooperative agreements with the South and the West, and is in the process of establishing one with a Northeastern group.

In addition to holding their own meetings, cooperative agreement groups participate in meetings of DOE's Transportation Coordination Group (TCG) and Transportation External Coordination (TEC) Working Group. The TCG, which meets annually, is DOE's vehicle for briefing stakeholders on activities in the waste management system and for soliciting input on various transportation issues and initiatives. Participants at TCG meetings include DOE staff and contractors, industry personnel, and state, tribal, and local government representatives. Cooperative-agreement groups have an

12Environmental racism is a term describing the alleged practice of siting lucally unwanted land uses in lower-income communities because the residents are powerless to uppose construction and desperate for the economic benefits these facilities often provide. Clearly, with a voluntary siting process, the charge of environmental racism is hard to sustain. 
opportunity to address the full TCG and comment on DOE's activities.

In June 1993, the TCG meeting included a panel discussion of full-scale cask testing, a subject of great interest among stakeholders for its publicconfidence implications. In response to comments on this first panel, DOE has decided to revisit the issue at its 1994 TCG meeting, allowing more stakeholders to join the discussion. DOE's willingness to address this subject at two meetings represents a major shift in attitude. For years, the agency resisted calls for full-scale cask testing on the grounds that such tests would have little scientific value. DOE now seems to be ready to concede that, while the tests might not reveal much new information on cask design, they might help demonstrate to the public the safety of shipping containers.

DOE's TEC Working Group offers stakeholders an even greater opportunity to contribute to transportation policy development. TEC Working Group members meet twice each year to discuss transportation issues that affect DOE as a whole (Table 5). Initially organized to address issues surrounding department-wide transportation emergency preparedness, the TEC Working Group has expanded its mission to address federal funding for state, tribal, and local training programs under the NWPAA, issues related to inspection and enforcement and emergency management, and specific public information and education initiatives.

TCG and TEC Working Group participants have expressed satisfaction in their ability to interact with DOE through these forums. Some groups have noted that DOE still needs to improve its work with the TCG and TEC Working Group, for instance by including more state, tribal, and local people at meetings (MHLW Committee 1993). Yet a growing consensus seems to be that, by convening these groups and responding to suggestions and comments raised during their meetings, DOE is demonstrating its desire to work cooperatively with affected and interested parties.

\section{Other Efforts to Involve the Public}

DOE's efforts to involve the public in decision making reflect a new department-wide policy of openness with a goal of changing its image as a closed and secretive bureaucracy (Cushman 1993). The department's decisions to declassify information about nuclear tests and to make public the nowfamous radiation tests of the 1940s and ' 50 s are further examples of the new policy in action.

DOE is also working to improve staff training to enhance their skills for communicating 
technical information to the public. Towards this end, DOE has developed a workshop on risk communication for personnel and contractors involved in radioactive waste management activities. This training emphasizes the importance of communicating effectively with the public and gives the staff the tools to use in situations such as press briefings and public hearings (DOE 1993b, 1).

In the summer of 1993, DOE sponsored a "Workshop on Developing a Consultative Process" to solicit suggestions for a process "through which interested parties could participate meaningfully in the civilian radioactive waste management program's direction and decision-making" (OCRWM 1993, 1). Participants at the workshop included state, county', and tribal representatives, labor unions, public interest groups, technical specialists, and utilities. Some participants, however, noted the absence of representatives from reactor and transportation corridor states and environmental groups (OCRWM 1993, 2).

Although no clear message or consensus came out of the workshop, the participants stressed that they wanted DOE to consider their views, and that DOE needed to be more accountable to the public in order to build trust. The participants also wanted involvement methods that are broad, open, and interactive, and discussed establishing a blue-ribbon panel to provide an independent review of nuclear waste management activities (OCRWM 1993, 3).

DOE is also working to build relationships with Indian tribes. For example, Yucca Mountain will sponsor a cultural resources program that will identify sites of cultural importance to minimize conflicts arising from site characterization (OCRWM 1991, 135-7). A cooperative agreement with the National Congress of American Indians (NCAI) provides funding for tribes to have input on waste management issues. NCAI maintains a list of tribes that may be affected by shipments of spent fuel. The cooperative agreement also makes it possible for tribal representatives to attend meetings of the TCG and the TEC Working Group.

\section{Midwestern Radioactive Waste Management Histories}

While Nevada's heated opposition to DOE's repository-siting activities attracts the most attention, it is important to note that other regions and other non-federal agencies have been and will continue to be embroiled in similar battles. From repository siting to interim storage to transportation, the Midwest has seen its share of controversies over radioactive waste management.

\section{Repository Siting in the Midwest}

Before the NWPAA, many sites across the country were targeted for study as possible sites for a repository. In fact, long before the controversy surrounding Yucca Mountain, the residents of Lyons, Kansas, challenged federal authority to site a storage facility for radioactive wastes. Although the site was geologically a poor candidate for a repository, a lack of communication between the Atomic Energy Commission (AEC) and the state complicated the process.

In 1970, delays in the program for reprocessing spent fuel increased the pressure to find a repository. The AEC announced tentative plans to convert an old salt mine into a repository. No studies of the integrity of the mine or its geologic or hydrologic surroundings were conducted, and some attribute this to the fact that the AEC did not want to delay the project (Jacob 1990), 36). The AEC did not know that the area had been excavated with solution mining, a process in which fresh water is injected into the salt and withdrawn as brine. This form of mining created an underground cavity onchalf mile wide and three-quarters of a mile long. If the cavity collapsed, large ponds could form near the repository. 
In 1971, a study found that out of all the sites under consideration for the repository, the Lyons site was the "poorest candidate." By then, state legislators and a U.S. senator from Kansas opposed the project. Although the AEC had underestimated the technical complexities involved in siting a repository, the commission's biggest failure, it has been noted, occurred in not securing the cooperation of state officials before announcing that Kansas was being considered for storage of the nation's nuclear waste (Carter 1987, 67-71).

DOE's predecessor, the Energy Research and Development Administration (ERDA), turned its attention to the salt beds underneath the northeast corner of the upper peninsula of Michigan in 1975. Michigan Governor William Milliken and Congressman Philip R. Ruppe distrusted the ERDA's claims that exploration was still in the preliminary stages, since the administration's own contractor said it was close to the final stages of selection. In a 1976 congressional hearing, wary legislators pointed to the Hanford leaks and the Lyons salt mines as evidence of federal mismanagement (Jacob 1990,55).

Michigan officials wanted assurances that no repository would be built without state approval. Although ERDA administrator Robert Seamens assured the state of this right, Michigan officials became concerned that the administration would overwhel $m$ them with evidence that would leave no choice but to approve the site. Milliken asked for activities in Michigan to stop, citing concern over the site's proximity to the Great Lakes and the potential "negative economic impacts" the state might suffer (Carter 1987, 149).

When the ERDA announced in 1976 that it planned to study Wisconsin as a possible candidate for a repository, Governor Patrick Lucey immediately began to monitor the process. Although studies were not pursued at the time due to lack of funds, "cooperative and constructive" relations developed between Wisconsin and the federal government, based primarily on the ERDA's assurance that studies would be withdrawn if the state objected (Schaefer 1988, 1).

When the effort was renewed in the late 1970s, however, the relationship had changed because attitudes toward nuclear power had changed. Although four reactors had been operating safely in the state for years, opposition stopped any new reactors from being built because of concern over the disposal of the waste. Shipments of spent fuel from the West Valley, New York, reprocessing plant back to Wiscunsin, the recognition of the need to store fuel at the reactors for longer periods than anticipated, and the Three Mile Island accident also helped to create this environment (Schaefer 1988, 2).

In 1979 and 1980, two DOE-sponsored documents surfaced. One was a draft environmental impact statement on radioactive waste disposal that included in the index a reference to a preferred site, interpreted by Wisconsin officials as referring to their state. This perception was dispelled by DOE, although the department indicated that the state might soon be included in the list of potential sites.

However, the governor soon found out through the media that DOE intended to begin siting work within a couple of months. Subsequent DOE briefings showed the public's hostility to this project, and citizens and environmental groups demanded that the governor take measures to ensure that all viewpoints were considered. Governor Lee Sherman Dreyfus formed the Committee on Radioactive Waste Management, comprised of the governor, legislators, board members from the county in question, citizens, and utility representatives (Schaefer 1988, 3-4).

The other document, prepared by a DOE contractor, identified areas of Wisconsin as among the most favorable for repository siting studies, and made the state even more suspicious of DOE. The Lake Superior region was identified as a possible area for study, and a map showed a stretch of granite under seven counties in the northern part of the state that looked promising. Governor Dreyfus denounced DOE for withholding information, but the department countered that the report would be released 
shortly and was not endorsed by DOE (Schaefer 1988, 5).

Governor Dreyfus was criticized for accepting DOE assurances too easily, and 25 local governments and the Great Lakes Inter-1 ribal Council acted to pass resolutions or referenda expressing upposition to a repository. The Wisconsin Department of Justice and the environmental group Safe Haven urged a decision of "no confidence" in DOE's ability to site a facility in the near future during an NRC Waste Confidence Rule Making Procedure. Dreyfus endorsed legislation giving the state absolute veto power over the siting decision (Schaefer 1988, 7).

In 1981, the legislature created the Wisconsin Radioactive Waste Review Board, although it met with resistance at first by a public that feared a group like this would signal willingness to work with DOE. At least half of the ten board members were to be from the general public, and it would serve as the primary state contact about all radioactive waste issues (Schaefer 1988, 8). The board also initiated public outreach activities, including mailings, listing meeting times in libraries, holding meetings at night and in parts of the state potentially affected, sending invitations to local government officials and tribes, establishing a toll-free hotline, and giving presentations to groups and at state fairs. The board also developed an education committee that produced slides, fact sheets, a newsletter, displays, presentations, information banks at libraries, and published a supplement to the Department of Natural Resources publications. The board was criticized for not promoting a balanced view and for instilling "fear," although the board saw its role as countering DOE's views (Schaefer 1988, 26).

Various DOE actions caused Governor Dreyfus to question the department's commitment to the "consultation and concurrence" to which both parties had agreed (Schaefer 1988, 10). During the Reagan Administration, this policy was changed to "consultation and cooperation," or one where DOE would unilaterally make the decisions. But Wisconsin began to have more of a cooperative relationship with, and was able to get information from, the newly opened (now closed) Crystalline Repository Project Office in Chicago.

The board soon officially opposed the repository, and also expressed concern over the transportation of waste, as Wisconsin would be affected by this aspect of the radioactive waste management program even if it did not host a repository. The state commented on DOE plans for spentfuel transportation, petitioned the NRC to make rules, initiated state legislation establishing an escort program, and urged reauthorization of the Price-Anderson Act to address transportation (Schaefer 1988, 22). Despite the relationship between the board and the Chicago office, the board's participation on workshops, and the passage of the NWPA, however, DOE could never dispel the board's negative view of DOE's repository siting efforts (Schaefer 1988, 12-20).

By 1986, siting efforts had ceased in the state. DOE's activities, as directed by the NWPA, would focus on Yucca Mountain, Hanford, and Deaf Smith County in Texas. Wisconsin attempted to eliminate the need for a second repository by supporting efforts to reduce the amount of waste produced (Schaefer 1988, 30-35). The opposition organized by the state, noted one analyst, was not "simply state v. federal, anti-nuclear v. pro-nuclear, or private good v. common good." The reaction to the repository program was the result of a well-coordinated combination of interests with a common goal (Schaefer 1988, 36).

\section{Spent-Fuel Storage Facilities}

Interim storage of spent nuclear fuel is a current challenge for many Midwestern reactors. By 1998, seven reactor pools in the Midwest are projected to lose full-core reserve (FCR), or the capability to empty the whole reactor; all but four of the existing pools are expected to run out of space before the repository is scheduled to open. 
Transshipment, or moving fuel from one facility to another owned by the same utility, can alleviate this storage crunch only to a limited extent. Interim storage involves removing the spent fuel rods from the pool and placing them in dry storage on the power plant site away from the reactor. Independent spent fuel storage installation (ISFSI) technology includes vertical, passively-cooled concrete or steel canisters, and vertical or horizontal concrete modules. ${ }^{13} \mathrm{~T}$ wo of the three nuclear plants in the Midwest that either are storing on site or will need to in the very near future have already discovered that the public fear of nuclear waste includes independent spent fuel storage installations.

\section{Palisades (Covert, Michigan)}

Consumers Power Company's Palisades Nuclear Plant near Covert, Michigan, was the first Midwestern reactor to lose FCR. Although the pool has twice undergone reracking ${ }^{14}$ in its 21 -year history, the Palisades plant effectively lost FCR with its last fueling cycle in 1992. In March 1990, Consumers Power applied for a site-specific license to store spent fuel in VSC-24 concrete casks. The NRC received over 50 letters requesting a hearing on the application (Haughney 1993, 2). Consumers Power withdrew its application for a site-specific license in August 1990 and indicated its intent to pursue dry cask storage through the NRC's newly promulgated general license provisions that do not require utilities to seek approval for waste-storage sites as long as the waste is stored in an NRCapproved containers (Regan 1993).

The NRC certified the VSC-24 cask in late April of 1993. Two casks have been fully loaded and the company expects to load 11 more in 1994. Consumers Power plans eventually to have a total of 25 casks in its ISFSI. The additional capacity gained through dry storage will enable the plant to maintain FCR until 2007, which is only a few years short of the expiration of its operating license.

Public opposition to dry-cask storage at the plant has been strong. This opposition has been fueled in part by the fact that the storage pad, and the plant itself, sits 300 yards from Lake Michigan. Consumers Power provided information to the local county commission, conducted tours of the plant, and participated in discussions of the proposed storage facility with the community. The county commission even held one of its regular meetings at the Palisades plant, with the meeting open to the public. Yet these attempts to involve the public did not quell all opposition to the project (CSG-MW 1993, 28). During the public comment period for the proposed rulemaking adding the VSC-24 cask to the list of approved storage casks, the NRC received over 190 comment letters, many specifically objecting to the use of the cask at the Palisades plant (Haughney 1993, 2).

Groups that were involved in attempting to stop the fuel from being loaded into the casks pointed to the location of the casks, the fact that this is the first time this cask will be used, and the nature of the waste, and displayed a lack of confidence in the NRC. Voicing many of the concerns that are common to critics of nuclear waste storage, a local resident told the NRC and the Van Buren County Board at a meeting in late 1992, ". . the whole thing has been very frustrating because we have been denied public hearings, there has not been an environmental impact statement, there has not been a cost benefit analysis, there has not been an economic impact statement, and the certificate of need has not been legislated"15 (Smith 1992).

In December 1992, at the urging of environmental groups such as Don't Waste Michigan, the Coalition for a Nuclear-Free Great Lakes, and Palisades Watch, State Attorney General Frank Kelly

"For more information on interim storage, see CSG-MW 1943.

Wtilities can increase storage capacity in spent fuel pools by reducing the spacing between assemblies.

${ }^{15}$ All these items were either addressed as part of the rulemaking process ur not required. 
wrote to NRC Chairman Ivan Selin to request a full public hearing on the use of dry storage casks at the Palisades plant. The NRC declined to hold such a hearing, but the commission agreed to meet with Kelly and other concerned groups in February to discuss the proposed ISFSI at Palisades. At the question-andanswer session, Kelly declared that "the people of Michigan can be well served only by a full, formal hearing on the issues" surrounding the dry storage facility (Grand Rapids Press 1993).

On May 6, Kelly filed a lawsuit to stop the loading of fuel into the casks, but a 6th district judge allowed the loading to continue. Kelly also sent a letter dated March 8, 1993, to all of the Great Lakes attorneys general asking for their support for a public hearing on the Palisades issue. The letter referred to a forthcoming petition to force the NRC to hold public hearings. The petition was never sent out, however, as Michigan decided to concentrate on legal action. The state has filed a suit charging that the NRC violated federal environmental laws when it did not prepare an environmental impact statement or an environmental assessment for dry storage at the plant (NCSL 1993b, 9). The suit is now before a federal appeals court.

\section{Prairie Island (Welch, Minnesota)}

The issue of interim versus permanent storage has entered the debate at Northern States Power's (NSP) Prairie Island Nuclear Plant in Minnesota. The plant is expected to lose FCR in 1995, despite the fact that its two pools have been reracked twice. The first reracking project took place in the mid-1970s, and the pools were again reracked in 1981, bringing the total capacity to its current 1,386 assemblies (MEQB A-9).

In 1991, NSP applied to the Minnesota Public Utilities Commission (MPUC) for a certificate of need to allow construction of an on-site dry storage facility. NSP proposed building a facility consisting of 48 metal casks (Transnuclear's TN-40 model) that would hold spent fuel aged at least 10 years. In August 1992, the MPUC approved the use of only 17 casks at the site, which would allow the plant to operate until the year 2000 without losing FCR. The commission also required NSP to build a berm around the storage pad to shield it from nearby residents and ensure full-core off load capacity for both reactor units. In addition, annual progress reports on DOE's activities with regard to developing an MRS facility must be submitted to the commission.

As part of the permitting process, the Minnesota Environmental Quality Board (MEQB) prepared an environmental impact statement for the proposed site. The Minnesota Department of Health provided input in the form of a health-risk assessment of the storage facility to determine acceptable off-site dose limits to the nearest permanent resident. The Department of Health decided upon a limit of $0.054 \mathrm{mrem}^{16}$ per year as a maximum, compared to the federal limit of 25 mrem per year. The MEQB requested that NSP change the location of the storage area, relocating the facility from the proposed site in the northwest corner of the property to the southwest corner.

NSP began construction of the storage pad in 1992, but in March of 1993, opponents of the dry storage plan, including the Prairie Island Sioux Tribe, the Coalition Against Nuclear Storage (CANS), and the Minnesota Public Interest Research Group requested that the Minnesota court of appeals overturn the MPUC ruling (Kerr 1993). This coalition claimed, and the federal courts agreed, that since the federal repository is not near completion, interim storage at Prairie Island will constitute defacto permanent storage, which required the approval of the Minnesota state legislature.

Since becoming the domain of the legislature, the issue of interim storage at Prairie Island has stirred emotions in the state and generated interest around the country. Even before hearings began,

1"The rem, or roentgen equivalent man, is the unit of measurement which defines the amount of damage tw human tissue from a dose of ionizing radiation. A millirem (mrem) in $1 / 1,(100)$ of a rem. 
in October of 1993, six state senators flew to Virginia Power's Surry Nuclear Power Plant to look at its dry-storage system, in operation since 1986. NSP officials went with the senators, angering environmental groups (Laszewski 1993c). Greenpeace covered an NSP billboard near the state capitol with their own banner that read "Nuclear Power = Nuclear Waste" and "Stop the Nuclear Dump at Prairie Island." February 23, Citizen's Lobby Day at the state capitol, culminated in a concert that featured national and local musicians.

Sen. Steve Novak's bill to allow NSP to store the waste also included provisions for NSP to move away from nuclear power to electricity generated by alternative energy sources. The bill passed the Senate Jobs, Energy, and Community Development Committee and the House Regulated Industries and Energy Committee, but was rejected by the Senate Environment and Natural Resources Committee. Opponents claimed that if NSP was allowed to store waste on site, the waste would remain there forever, and NSP would have no incentive to move toward alternative sources (Minnesota Senate 1994, 1). The measure was tabled then finally passed the Senate by a vote of 42 to 24 . The House Environment and Natural Resources Committee, however, may kill the proposal for the 1994 legislative session, or may approve a bill that denies NSP's request (Coffman 1994b). During this emotionally charged debate, two legislators received death threats because of their support of the project (Coffman 1994a).

The Institute for Local Self-Reliance, a non-profit group promoting sustainable economic development through a variety of avenues including alternative energy sources, has estimated that NSP could rerack the pools a third time and keep the plant operating until 2001, while looking at ways to replace the electricity the plant generates in the interim. For instance, NSP could purchase power from other power producers, or could use co-generation, a technology that involves attaching generators to factories and capturing waste heat (Laszewski 1993a). In the long run, Minnesota could replace the 15 percent of electricity that Prairie Island generates with wind power, biomass-fueled plants, and efficiency programs. But these measures would increase costs over the short term as electricity is imported from out of state and new energy sources are constructed. This, says the institute, is "the price we have to pay for having believed the federal government that we would never have to take responsibility for our own radioactive wastes" (Morris 1993).

Discussions surrounding the Prairie Island issue have raised questions about environmental racism, both in Minnesota and in other parts of the country. Prairie Island Sioux opponents of the storage plan have said that they have borne a risk for too long and do not want any more waste near their community ${ }^{17}$ (Laszewski 1993b). But the Mescalero Apaches, the tribe that progressed the farthest towards hosting an MRS facility, has shown an interest in hosting the waste. The tribe recently signed an agreement with NSP as a first step towards establishing a private, commercial MRS facility. NSP contacted other waste generators about joining the venture. The facility would accept waste for a negotiated period of time or until the federal government begins accepting the waste (Mescalero Apache Tribe 1994). However, the state of New Mexico has already expressed opposition to this plan (New Mexico Governor's Office 1994).

\section{Point Beach (Truo Creeks, Wisconsin)}

Wisconsin Electric Power Company's (WEPCo's) Point Beach Nuclear Plant in east-central Wisconsin, located a half-mile from Lake Michigan, will run out of storage space in 1994. WEPCo has proposed expanding its on-site storage capacity through the use of concrete casks under a general license. In November 1991, WEPCo applied to the Public Service Commission of Wisconsin (PSCW) for a certificate of authority to construct 12 casks and a storage facility sized to hold a maximum of 48 casks. The storage capacity gained with the first 12 casks would take the plant through 1998 with FCR. The

This ISFSI will only store spent fuel from I'rairie Island. 
full 48 casks would provide sufficient on-site storage through the life of the plant. In 1994, the PSCW will decide if WEPCo will be permitted to build the system (Bergquist 1993).

Since submitting the application nearly a year and a half ago, WEPCo has been discussing the proposal formally and informally with the PSCW staff, plant neighbors, and other interested groups throughout the state. ${ }^{18}$ The PSCW has indicated that it, too, will ensure that the public is involved in the review of the WEPCo dry storage proposal. As part of its treatment of the application, the PSCW published a draft environmental impact statement in February 1994. After holding informational meetings and collecting comments on the environmental impact statement in the spring, the PSCW expects to issue the final report in the summer of 1994 and make a decision about the casks shortly afterward (Rauh 1994; PSCW 1994, ii).

In addition, as part of the review process, interested parties in Wisconsin could apply for funding, provided by the utility, to conduct independent studies of the proposal. PSCW estimates that over $\$ 140,000$ of ratepayer money will be given to public interest groups who oppose storage. The Wisconsin Citizens Utility Board (WCUB) commissioned a study of the total costs of nuclear power, including both real economic costs and the costs to society, and has made the storage of nuclear waste a priority. Another group, the Lake Michigan Federation, does not oppose nuclear power but does want WEPCo to ensure the safety of the surrounding area by using more expensive storage technology.

As with Prairie Island, another issue surrounding the Point Beach dry storage facility is whether interim storage will become permanent if there are further delays in the federal system. ${ }^{19} \mathrm{WCUB}$ and PSCW have expressed serious doubts about the government's ability to solve the radioactive waste management problem (Bergquist 1993). In a March 1993 letter to Secretary O'Leary, PSCW made a plea for a quick solution to the radioactive waste rnanagement problem, indicating that they will spend $\$ 13$ million for on-site storage at Point Beach, and that the state's other plant, Kewaunee, will soon face similar problems (Parrino et al. 1993).

\section{Monitored Retrievable Storage Facility}

A few jurisdictions in Midwestern states have considered hosting an MRS facility. One of the more dramatic cases of public opposition to a siting study occurred in Grant County, North Dakota. In 1992 , county officials applied for and received a $\$ 100,000$ grant to study the feasibility of hosting an MRS facility. Opponents of the study, calling themselves "Citizens Against a Nuclear Waste Dump in Grant County," asked the commissioners to stop work on the grant. When the commissioners refused, opponents organized a special recall election which resulted in all three county commissioners losing their seats. Records show the commissioners spent most of the grant money between January and March of that year, with nearly $\$ 59,000$ going to their consultants, Nuclear Assurance Corporation, to set up an information office in the county, develop a brochure, and obtain legal services. At the time of the recall, work on a Phase II application had already begun, and NAC was planning to assess local attitudes toward the facility (NWN 1992b).

An independent review team was appointed to study why the grant process fell through in Grant County. The study found that the commissioners never publicly explained the study to the citizens, who did not know of the nuclear waste negotiator or that the county was under no obligation to host an MRS facility after accepting grant money, and felt that DOE had targeted them to host the site (White Tail Feather 1993, 2).

\footnotetext{
${ }^{18}$ Although the Wisconsin Legislature has no oversight authority, the Assembly Environmental Resources Committee held meetings to provide information to the public and to lawmakers.
}

"WEPCo estimates that the casks will be used until 2030. 
Residents of another North Dakota county voted in June of 1992 against proceeding with an application for a Phase I feasibility grant. Adams County commissioners had placed the job of educating the residents with the Adams County Economic Development Corporation, a board of local volunteers. The group held public meetings, provided written information, and held discussions on local talk radio shows (NCSL 1992, 8).

The Prairie Island Sioux, the same tribe that opposed interim storage in Minnesota, was awarded a Phase I grant in 1992 and applied for a Phase II grant in 1993. The tribal council voted to end this study in June of 1993, and the Phase II grant application was withdrawn. Some of the grant funds were used to survey the tribal members, who overwhelmingly opposed the MRS facility. The tribe has indicated that if NSP receives permission to store spent nuclear fuel at the Prairie Island Plant, which is accessed through Sioux land, the tribe may relocate its reservation (NCSL 1993b, 10).

The Wayne County Development Corporation in Wayne County, lowa, also investigated the possibility of volunteering to host an MRS facility. Because of public outcry, however, even the possibility of studying a site was abandoned. One reaction to that proposal included a bill that would mandate legislative approval of any storage of spent nuclear fuel in the state. The bill was endorsed by the Senate Natural Resources Committee but did not make it through the lowa House (Des Moines Register 1993). The former president of the Wayne County Development Corporation circulated petitions supporting the study, saying that residents were not aware of the benefits of an MRS facility (Beeman 1993).

\section{Transportation}

For an idea of how a large shipping campaign is conducted, Midwestern states can review the transport of damaged fuel rods and other debris from Three Mile Island to Idaho National Engineering Laboratory (INEL). Ohio, Indiana, Illinois, Missouri, Kansas, and Nebraska were affected by the shipments. Environmental impact statements following the accident concluded that Three Mile Island was not suited for long term storage of spent nuclear fuel. The campaign began in 1986 and ended in 1990, 22 train shipments later, and was coordinated among DOE, the NRC, General Public Utilities Company, the Federal Rail Administration, and affected railroads and states (Figure 2).

A three-year cask-development process preceded the campaign. The containers were designed to provide greater protection against radioactivity than casks designed for undamaged spent fuel, and were subjected to scale cask tests. Route selection focused on transport over the shortest, most direct routes and high-quality track and avoidance of high-population areas. The entire route was inspected before and during the shipments. Emergency plans for hazardous materials incidents were supplemented with special emergency response teams to accommodate the damaged fuel (GAO 1987, 3-4). States ma intained local control over the shipments. In East St. Louis, the Illinois Department of Nuclear Safety (IDNS) and the Missouri Bureau of Radiológical Health conducted inspections, and Missouri again inspected the cask before it left the state.

A 1989 report by the U.S. Department of Transportation's Research and Special Programs Administration reviewed DOE's process for selecting the rail route for the shipments. The study found that DOE did not have well-developed guidelines for route selection, but noted that DOE issued guidelines soon after DOT began looking at the shipments. Even under these new guidelines, however, DOE did not give high priority to wayside population exposure because the department had confidence in the integrity of the shipping casks (RSPA 1989, vi). DOT also noted that the shipments traveled on high quality track, and the campaign used the shortest shipping route and had minimal switching delays. This was due to the fact that only two carriers participated in the campaign, although one carrier's performance was judged to be below industry norm (RSPA 1989, v). 


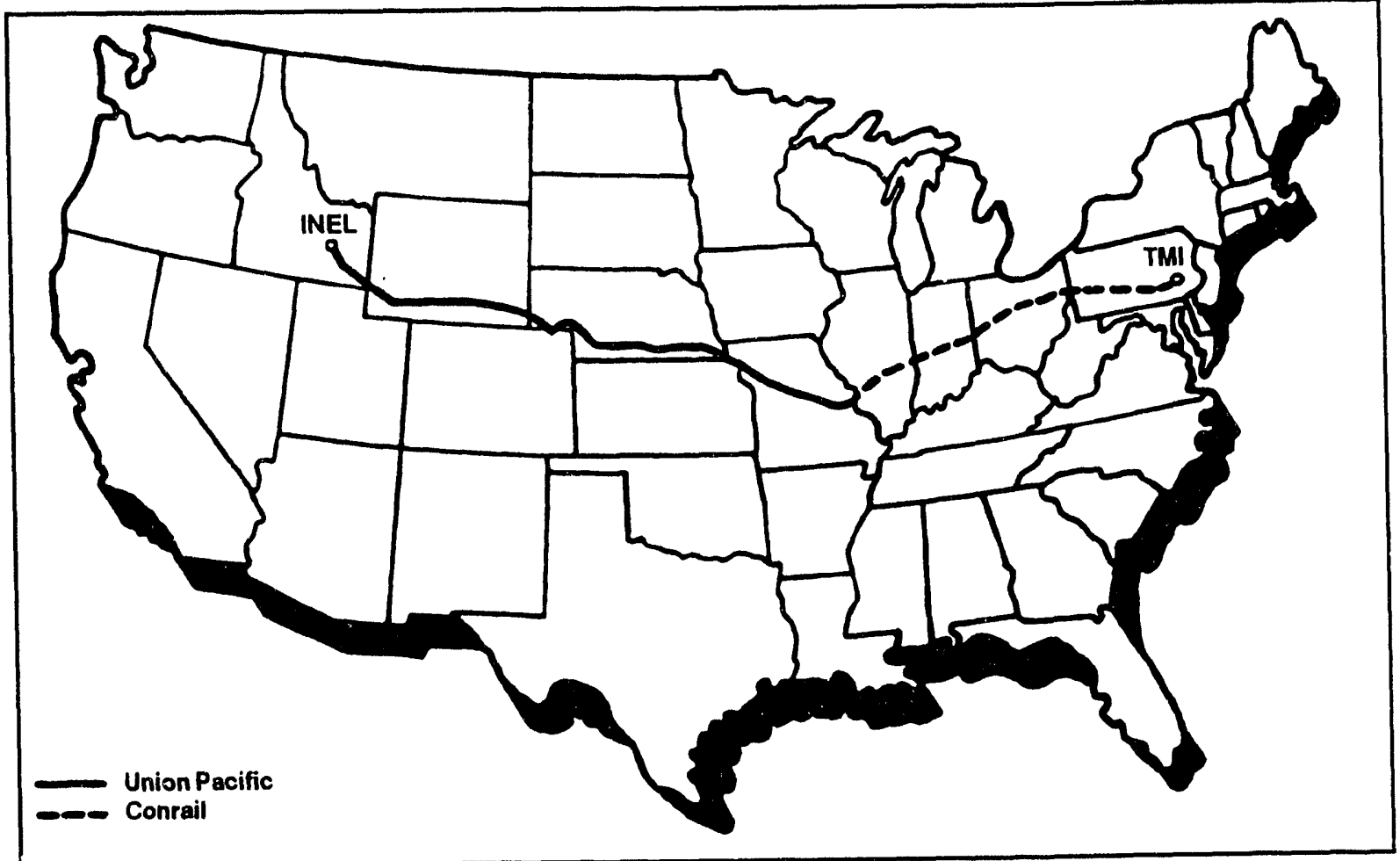

Figure 2. Route of Three Mile Island Spent Fuel Shipments Source: GAO 1987, 30.

Several minor incidents occurred during the campaign. Early in the campaign, an unrelated rail accident involving hazardous materials occurred in Ohio, resulting in a 5-day fire and the evacuation of thousands of people. DOE considered changing its shipping route based on experiences gained from this accident. The department eventually decided that if Three Mile Island shipments were involved in a similar accident, there would not be any need for evacuation, nor would the shipping cask fail (GAO 1987, 29, 32). A crossing accident in St. Louis involved a campaign train and a car, however, the radioactive cargo was not affected. In East St. Louis, a buffer car was mislabeled as carrying a flammable material (RSPA 1989, 3).

The report documented public opposition to the campaign, with most of the concerns coming from the cities of St. Louis and Pittsburgh and the states of Kansas and Illinois. One concern expressed by the governor of Kansas and others was that DOE had not prepared an environmental impact statement for the campaign. DOE countered that the shipments were "substantially the same as" other actions that had already been evaluated for possible environmental impact (RSPA 1989, 1).

\section{Education Efforts}

Many states, especially those dealing with siting issues, have launched public education efforts that make use of many different media and formats. Although some of these efforts address low-level waste (LLW) issues, any public education efforts should be evaluated for their effect on public opinion about radioactive waste.

IDNS sponsors exhibits at the lllinois State Fair and county fairs, demonstrating radiation protection and detection equipment, handing out information, and answering questions about radiation and IDNS programs. The department's primary public-information product related to high-level waste is The Illinois Experience: Spent Nuclear Fuel and High Level Radioactive Waste Inspection and Escort Program. 
This brochure describes the program, along with explaining what is shipped and how it is packaged. According to Patty Thompson, Director of Communications for IDNS, high-level radioactive waste "does not generate a lot of interest," and therefore is not a current focus of information programs.

Although a video produced by IDNS, And the People Will Decide (1988), deals with attempts to site a low-level waste facility at Martinsville or Wayne County, the effort touches on various general issues in the public debate about nuclear waste storage. In the video, two local residents voice typical fears about nuclear power, linking it with Three Mile Island, Chernobyl, explosions, and death. But both go on to describe how they educated themselves, by visiting other low-level waste sites, attending meetings, reading material provided by libraries, and working with IDNS.

Other local citizens on the video - including a newspaper editor, county officials, and a member of the siting committee who is also a doctor - stress the safety and economic benefits of the site. Former IDNS director Terry Lash emphasizes his work with environmental groups and details the engineering of the site. The residents express a willingness to give up a little land for the greater good, and the narrator stresses that ultimately, the choice is in the hands of the people of Illinois. During the siting process, IDNS also nosted activities such as a "Career Day" for Martinsville High School students to educate them about the employment possibilities from a LLW site (IDNS 1989, 8). ${ }^{20}$

Utilities are also involved in public education efforts. The Palisades plant, along with public information brochures, provides speakers to schools, civic groups, or businesses on energy-related topics. Indiana-Michigan Power's Donald C. Cook Plant in Bridgman, Michigan, houses the Cook Energy Information Center. Visitors can watch a video tour of the plant and demonstrations of how the plant works. Computers and interactive videos allow visitors to conduct energy experiments and learn about energy, radioactive waste management, and radiation shielding.

Northern States Power launched a campaign in 1993 to educate Minnesota residents about the issues surrounding the proposed storage facility at its Prairie Island plant. An ad campaign in the St. Paul Pioneer Press featured plant workers testifying to the safety of storing spent nuclear fuel on the plant site and assuring that the storage is temporary. A toll-free number allowed concerned parties to listen to two tapes. One tape assured citizens that Prairie Island has an excellent safety record and that drycask storage will only add $2 / 100$ of a mrem per year to the area, which will not be detectable by the nearest neighbor. The tape informed people that the NRC allows 25 mrem a year from interim storage, 1,000 times what will be at Prairie Island, and reminded those concerned that radiation is a natural part of the environment.

Another tape dealt specifically with the storage system sought by NSP, describing the type of cask that will be used, the fact that it has been approved by the NRC, other plants that have dry-cask storage, and the economic effects of a premature shut-down should NSP not be allowed to store fuel on site. For example, NSP estimated that the nearby Red Wing school district would lose $\$ 10$ million in taxes, and 500 employees would lose their jobs. The tape ended with information on how pro-storage citizens can contact their state representatives.

Other institutions and groups have developed outreach programs. The University of Nebraska at Kearney sponsored two two-day workshops for high school science teachers called "Nuclear Technology: Benefits vs. Risks." According to John Rohrs, professor emeritus of nuclear physics at the university and the originator of the program, the workshops show teachers how nuclear materiais are used and cared for. The workshops were held at the Nebraska Public Power District's Gerald Gentleman Power Station and at Omaha Public Power District's Fort Calhoun Nuclear Plant. Both power districts also provided funding for the workshops.

:The siting commission rejected the Martinsville site in 1992. 
Teachers received one hour of university credit and participated in sessions on fundamentals of nuclear science, radiation safety issues, nuclear waste disposal, fears and attitudes about nuclear technology, and careers in the nuclear field. State radiation control officials, plant managers, and university professors presented the sessions. Rohrs says that the teachers' response to the program has been good, and he hopes to continue the program and expand it to provide regular courses for teachers (Rohrs 1993). The workshops are especially relevant to Nebraska teachers because of Nebraska's recent efforts to site a low-level waste facility and also because the state will most likely be a major transportation corridor if the high-level waste repository is located in the west.

The Ohio Radioactive Materials Users Group (ORMUG), made up of the various medical, industrial, university, utility, and research generators of radioactive waste in the state, seeks to educate the public and legislators about radioactive materials. According to Paul Sieck, a retired radiation safety officer and ORMUG's administrative director, the group focuses mostly on low-level waste issues, although some of its members are nuclear power generators. ORMUG has published many position papers on topics such as radiation safety, efforts of Ohio low-level waste generators to minimize waste, the importance of siting a low-level waste facility, safeguards for packaging and shipping low-level waste, and potential job losses if a site is not found (Sieck 1993).

\section{Conclusion}

A common theme emerges from the preceding discussion: public opinion matters. Unfortunately for people involved in radioactive waste management, these "opinions" usually take the form of public opposition - whether a small group of citizens organizes to stop construction of an interim storage facility or an entire state digs in its heels in a battle with the federal government. Public opposition can impede the progress of and significantly increase the costs associated with any major project, public or private.

Because of their deep-seated fear of radiation, people are especially loathe to accept activities in their communities that involve nuclear technology. In the case of civilian radioactive waste management, the spectre of radiation is compounded by the fact that people simply do not trust DOE, nor are they confident that the department is capable of handling this responsibility. Acknowledging this fact and understanding how past events and mental strategies shape these attitudes are important for devising solutions to the problem of radioactive waste management.

DOE has tried several ways of dealing with public opposition. In moving from repository siting to MRS-facility siting to transportation, DOE has progressed from the confrontational "decideannounce-defend" approach toward what can truly be called consultation and cooperation. It remains to be seen whether the transportation system operating a decade from now will resemble the one envisioned by the state, tribal, and local people working with DOE today. There is even a good chance that people will still object to radioactive-waste shipments through their communities despite their input or that of their government officials in developing the transportation system. Nevertheless, DOE has hit upon the right approach to its problem with public trust and confidence. By involving stakeholders in decisions regarding radioactive waste management, the department can reduce public opposition to its programs while at the same time rebuilding its image in the public eye. 
Public Participation in Radioactive Waste Management Decisions

\section{References}

Nuclear Waste News (NWN). 1992a. DOE Shifts Gears on MRS; Negotiator Cries 'Foul.' 12(471).

1992b. North Dakota Commissioners Unseated in Recall Election Over MRS. 12(106).

1993a. DOE Streamlines Hanford Tank Management, Speeds Cleanup. 13(364).

1993b. Get Out of Town, Miller Tells DOE, Yucca Mountain Project. 13(162).

1993c. OCRWM to Hold Teachers' Teleconference in April. 13(58).

1993d. Yucca Mountain Project Divides Nevada Officials. 13(163).

1994. Slants and Trends. 14(1).

Allen, Scott. 1993. If we can't bury nuclear waste in Nevada, where can we? The Boston Globe, May 17.

Balogh, Brian. 1991. Chain Reaction: Expert Debate and Public Participation in American Commercial Nuclear Power, 1945-1975. New York: Cambridge University Press.

Beeman, Perry. 1993a. Nuclear facility study scrapped. Des Moines Register. February 16. 1993b. Petition urges study of storage facility for nuclear waste. Des Moines Register. March 25.

Bergquist, Lee. 1993. Nuclear fuel: waste that won't go away. Milwaukee Sentinel. September 1.

Bisconti, Ann S. 1992. Public Attitudes about Radioactive Waste. In High Level Radioactive Waste Management: Proceedings of the Third Annual International Conference. La Grange, IL: American Nuclear Society and American Society of Civil Engineers; pp. 1-3.

Bisconti, Ann S., and Robert L. Livingston. 1992. Communicating with the Public About Radiation: An Assessment of Public Attitudes About Radiation, and Their Implications for Communication and Education Programs. Washington, DC: U.S. Council for Energy Awareness.

Carter, Luther J. 1987. Nuclear Imperatives and Public Trust: Dealing with Radioactive Waste. Washington, DC: Resources for the Future, Inc.

Casamayou, Maureen Hogan. 1993. Bureaucracy in Crisis: Three Mile Island, The Shuttle Challenger, and Risk Assessment. Boulder; CO: Westview Press.

Church, Foster. 1990. Can Nevada Keep America's Sizzling Nuclear Waste out of its Backyard? In Governing. April.

Coffman, Jack B. 1994a. Nuclear Storage Approved. Saint Paul Pioneer Press. March 31.

1994b. NSP predicts higher prices if storage denied. Saint Paul Pioneer Press. April 13.

Council of State Governments, Midwestern Office (CSG-MW). 1993. Report on Interim Storage of Spent Nuclear Fuel. Lombard, IL: CSG-MW.

1994. Midzuestern High-Level Radioactive Waste Transportation Primer. Lombard, IL: CSG-MW. 
Cushman, John H. 1993. Cold War Secret Revealed: 204 Nuclear Blasts by U.S. The New York Times. December 8 .

Dantico, Marilyn K., Alvin H. Mushkatel, and David Pijawka. 1991. Political Trust's Role in Explaining Nevada Urban Residents' Perceptions of the Proposed Yucca Mountain Repository. In High Level Radioactive Waste Management: Proceedings of the Second Annual International Conference. La Grange, IL: American Nuclear Society and American Society of Civil Engineers; pp. 748-756.

Des Moines Register. 1993. Bill aimed at storage of spent nuclear fuel. March 16.

Eureka County Yucca Mountain Project Information Office (Eureka County Information Office). 1993a. $\mathrm{Q} \& \mathrm{~A}$ on Transportation. Nuclear Waste Update (1)4; Fall.

Flynn, James. 1992. How Not to Sell a Nuclear Waste Dump. The Wall Street Journal. April 15.

Flynn, James, C.K. Mertz, and Paul Slovic. 1991. The 1991 Nevada State Telephone Survey: Key Findings. Carson City, NV: Decision Research: Yucca Mountain Socioeconomic Project.

Flynn, James, Roger Kasperson, Howard Kunreuther, and Paul Slovic. 1992. Time to Rethink Nuclear Waste Storage. Reprinted from Issues in Science and Technology 8(4); 42-48.

General Accounting Office (GAO). 1987. Shipping Damaged Fuel from Three Mile Island to Idaho. Washington, DC: GAO. GAO/RCED-87-123.

Gilbert, L., and M. Robinson. 1992. Social and Science Issues in the Local Environment. In High Level Radioactive Waste Management: Proceedings of the Third Annual International Conference. La Grange, IL: American Nuclear Society and American Society of Civil Engineers; pp. 1813-1817.

Gomberg, Steve. 1993. OCRWM Update. Presentation to the Southern States Energy Board's Advisory Committee on High-Level Radioactive Waste (Richmond, VA; September 20).

Grand Rapids Press. 1993. Kelly, environmentalists urge hearing on nuke fuel storage. February 24.

Greenberg, Phillip A. 1993. Dreams Die Hard. In Sierra: The Magazine of the Sierra Club. November/ December.

Haughney, Charles J. 1993. Letter to Lisa R. Sattler. March 9.

Illinois Department of Nuclear Safety (IDNS). 1988. And the People will Decide. Springfield, IL: IDNS.

- 1989. IDNS Nuclear Safety Update. Summer.

Jacob, Gerald. 1990. Site Unseen: The Politics of Siting a Nuclear Waste Repository. Pittsburgh: University of Pittsburgh Press.

Kerr, John. 1993. Status of High-Level Radioactive Waste Issues in Minnesota.

Kunreuther, Howard, and Ruth Patrick. 1991. Managing the Risks of Hazardous Wastes. Environment $3(33)$.

Laszewsk.i, Charles. 1993a. Energy plan offers alternative to Prairie Island nuclear plant. Saint Palıl Pioneer Press. October 20. 
Public Participation in Radioactive Waste Management Decisions

1993b. Nuclear waste storage opposed. Saint Paul Pioneer Press. November 23.

1993c. Six lawmakers to tour Virginia nuclear plant. Saint Paul Pionteer Press. October 14.

Leroy, David. 1993. 1992 Annual Report to Congress. Boise, ID: Office of the United States Nuclear Waste Negotiator.

Lewis, H.W. 1990. Technological Risk. New York: Norton.

Mandra, York T. 1992. Phobias and Underutilization of University Scientists: A Suggested Program. in High Level Radioactive Waste Management: Proceedings of the Third Annual International Conference. La Grange, IL: American Nuclear Society and American Society of Civil Engineers; pp. 1799-1806.

Mescalero Apache Tribe. 1994. Mescalero Apache Trive and Midwest Utility Sign Agreement Related to Spent Fuel Storage. February 3.

Midwestern High-Level Radioactive Waste Committee (MHLW Committee). 1993. Letter to Susan Smith. August 30.

Minnesota Environmental Quality Board (MEQB). 1991. Envirommental Impact Statement: Prairie Island Independent Storage Installation.

Minnesota Senate. 1994. NSP bill halted. In Briefly: The Minnesota Senate Week in Review. March 18.

Morris, David. 1993. Coming Prairie Island decision great chance to alter future. St. Paul Pioneer Press. October 28.

National Conference of State Legislatures (NCSL). 1992. High-Level Radioactive Waste Newsletter. August.

1993a. High-Level Radioactive Waste Nervsletter. June.

1993b. High-Level Radioactive Waste Newsletter. August.

1993c. High-Level Radioactive Waste Newsletter. December.

Nealey, S.M., and F.A. Morris. 1993. Fear of Permanence: The Challenge of Siting Interim Facilities. In High Level Radioactive Waste Management: Proceedings of the Fourth Annual International Conference. La Grange, IL: American Nuclear Society and American Society of Civil Engineers; pp. 18851889.

New Mexico Governor's Office. 1994. News Advisory, February 3.

Nuclear Waste Policy Act (NWPA), P.L. 97-425, as amended by P.L. 10(1-203 and P.L. 1(0)-507.

Nuclear Waste Technical Review Board (NWTRB). 1991. Fourth Report to the U.S. Congress and the U.S. Secretary of Energy. Washington, DC: NWTRB

1992. Fifth Report to the U.S. Congress and the U.S. Secretary of Energy. Washington, DC: NWTRB.

Office of Civilian Radioactive Waste Management (OCRWM). 1991. Draft Mission Plan Amendment. Washington, DC: OCRWM. DOE/RW-0316P. 
1993. Workshop on Developing a Consultative Process. Summary of Discussion and Suggestions. August 10.

Omaha World-Herald. 1993. Providing Storage for N-waste Could Mean Windfall. September 2.

Parrino, Cheryl L., John T. Coughlin, and Scott A. Neitzel. 1993. Letter to Secretary of Energy Hazel O'Leary.

Power, Max, Bob Robison, Douglas Larson, and Jim Miernyk. 1993. From DAD to TRAIN: Evolution of State-Federal Relations in Radioactive Waste Transportation.

Public Service Commission of Wisconsin (PSCW). 1994. Draft Environmental Impact Statement, Point Beach Nuclear Power Plant Projects.

Rauh, Jeff. 1994. Nuclear Information Coordinator, Wisconsin Electric Power Company, Point Beach Plant. Personal communication. March 7.

Regan, Mary Beth. 1993. Nuclear Fuel Rods in Sand Dunes? Business Week. May 10.

Research and Special Programs Administration, U.S. Department of Transportation (RSPA). 1989. Review of the Selection of the Rail Route for Shipping Three Mile Island Debris. Cambridge, MA: DOT/RSPA. SS-42-V1. 1-57 (r).

Resnikoff, Marvin. 1983. The Next Nuclear Gamble: Transportation and Storage of Nuclear Waste. New York, NY: Council on Economic Priorities.

Rohrs, John. 1993. Professor Emeritus of Nuclear Physics, the University of Nebraska at Kearney. Personal communication. November 1.

Rothman, Stanley, and S. Robert Lichter. 1987. Elite Ideology and Risk Perception in Nuclear Energy Policy. American Political Science Review 81(2):383-404.

Schaefer, Jame. 1988. State Opposition to Federal Nuclear Waste Repository Siting: A Case Study of Wisconsin 1976-1988. Green Bay, WI: University of Wisconsin-Green Bay Center for Public Affairs.

Scull, Roberta. 1992. An Interdisciplinary Approach to Learning and Teaching About Nuclear Waste Management. In High Level Radioactive Waste Management: Proceedings of the Third Annual International Conference. La Grange, IL: American Nuclear Society and American Society of Civil Engineers; pp 1807-1812.

Secretary of Energy Advisory Board Task Force on Radioactive Waste Management (SEAB Task Force). 1993. Earning Public Trust and Confidence: Requisites for Managing Radioactive Waste (Final Report).

Sieck, Paul. 1993. Executive Director, Ohio Radioactive Materials Users Group. Personal communication. November 1.

Slovic, Paul. 1987. Perception of Risk. Science 236(4799): 280-285.

1990. Perception of Risk from Radiation. In Proceedings of the Twenty-Fifth Ammal Meeting of the National Conncil on Radiation Protection and Measurements, pp. 73-97. Bethesda, MD: NCRP.

1991. Perception of Risk and the Future of Nuclear Power. In Proceedings of the First MIT 
Public Participation in Radioactive Waste Management Decisions

International Conference on the Next Generation of Nuclear Power Technology, pp. 1-6. Cambridge, MA: MIT.

Slovic, Paul, Mark Layman, and James H. Flynn. 1991. Lessons From Yucca Mountain. Environment 33(3).

Smith, Rod. 1992. Plans to Store Nuclear Waste in Casks Debated at Palisades. Kalamazoo Gazette, December 9.

South Dakota Argus Leader. 1993. Indians protest use of land for nuclear waste storage. August 12.

Southwestern Social Science Research Center (SSSRC). 1993. Nuclear Issues Survey — Spring 1993. Las Vegas, NV: University of Nevada-Las Vegas.

Strolin, Joe (Nevada Nuclear Waste Project Office). 1994. Personal communication. April 7.

Teer, Bill R. 1993. OCRWM Transportation Program. Presentation before the Midwestern High-Level Radioactive Waste Committee (South Bend, IN). May 7.

Thompson, Patty. 1993. Illinois Department of Nuclear Safety Director of Communications. Personal communication. November 1.

Tversky, Amos, and Daniel Kahneman. 1986. Judgement under uncertainty: Heuristics and biases. In ludgement and Decision Making: An Interdisciplinary Reader. New York: Cambridge University Press.

U.S. Council for Energy A wareness (USCEA). 1993. Nuclear Energy Info (October).

U.S. Department of Energy (DOE). 1992. DOE's Yucca Mountain Studies. Las Vegas, NV: Yucca Mountain Site Characterization Project. DOE/RW-0345P.

1993a. Science, Society, and America's Nuclear Waste: The Nuclear Waste Policy Act. Washington, DC: OCRWM. DOE/RW-0363 TG.

1993b. Transportation Risk Communication: Hazardous Materials Modular Training Program. Participant Workbook. Oak Ridge: Office of Special Programs.

—. 1993c. U.S. Department of Energy TEC Working Group Charter.

U.S. Nuclear Regulatory Commission (NRC). 1992. Public Information Circular for Shipments of Irradiated Reactor Fuel. Washington, DC: Office of Nuclear Material Safety and Safeguards. NUREG-(1725, Rev. 8.

Watson, Russell, Daniel Gluck, Mark Hosenball, and John McCormick. 1993. America's Nuclear Secrets. Newsweek. December 27.

Weart, Spencer. 1988. Nuclear Fear: A History of Images. Cambridge, MA: Harvard University Press.

Wells, Barbara. 1993. A Governor's Guide to Environmental Risk Response. Washington, DC: National Governors' Association Natural Resources Policy Studies Center for Policy Research.

White Tail Feather, Alex. 1993. Monitored Retrievable Storage of Spent Fuel: 1992 Update. Denver: NCSL. 


\title{
Midwestern High-Level Radioactive Waste Transportation Project
}

\author{
Publication Order Form
}

To order publications, indicate the quantity of each document you wish to receive, complete name and address information below, and return this form to:

Midwestern Office

The Council of State Governments

641 E. Butterfield Road, Suite 401

Lombard, IL 60148-5651

708/810-0145 (fax)

Name:

Title:

Company:

Address:

Phone:

Fax:

Public Involvement in Radioactive Waste Management Decisions, April 1994, 31 pages, DOE/

RW/00286-3. This report analyzes public involvement in decision making as a means of garnering acceptance of, or reducing public opposition to, DOE's radioactive waste management activities. The report reviews DOE's low level of credibility among the general public and the department's attempts to improve its standing with the public. The report also includes a section on public involvement in selected Midwestern facility-siting and transportation activities involving radioactive materials

Midwestern High-Level Radioactive Waste Transportation Primer, February 1994, 100 pages, DOE/RW/(0)286-2, Revision 1. A major milestone for the Transportation Project, the Primer discusses the objectives and challenges to implementing the federal Nuclear Waste Policy Act, with a focus on the institutional issues surrounding the transportation of spent nuclear fuel and high-level radioactive waste.

Report on Mutual Aid Agreements for Radiological Transportation Emergencies, December 1993, 16 pages, $\mathrm{DOE} / \mathrm{CH} / 1(14012-4$, Revision 1 . This report looks at existing interstate emergency response mutual aid agreements in the Northeast, South, and West, along with other examples of interstate cooperation, and examines how similar agreements among Midwestern states may facilitate emergency response to transportation accidents involving radioactive materials. A Model State Mutual Aid Agreement is included as an appendix to this report, and pr ivides a model of a state mutual aid agreement that could serve as a starting point for discussion between Midwestern state officials interested in forming such an agreement for transportation emergencies involving radioactive materials.

Midwestern Radiological Emergency Preparedness and Response Agency Report, July 1993, 55 pages. DOE / CH/10402-2, Revision 1. For the twelve Midwestern states, this document 
reports on state agencies with emergency preparedness and response duties, providing specific information on radiological emergency response plans, agency responsibilities, contacts at the state level, and inventories of equipment for use during a radiological emergency.

Report on Interim Storage of Spent Nuclear Fuel, April 1993, 34 pages, DOE/CH/104(1)2-22. This report discusses the technical, regulatory, and economic aspects of spent-fuel storage at nuclear reactors, and is intended to provide legislators, state officials, and citizens in the Midwest with information on spent-fuel inventories, current and projected additional storage requirements, licensing, storage technologies, and actions taken by various utilities in the Midwest to augment their capacity to store spent nuclear fuel on site. Updated supplement will be issued in 1994.

Handbook of High-Level Radioactive Waste Transportation, October 1992, 44 pages, DOE/CH/ 10402-19. This document condenses and updates information first presented in the Midwestern High-Level Radioactive Waste Transportation Primer. The Handbook serves as a reference to which state officials and the general public can turn for information regarding radioactive waste transportation and the federal Civilian Radioactive Waste Management Program.

Highway Infrastructure Report, February 1992, 26 pages, DOE/CH/10402-16. This document compiles information on recent or planned state- and county-sponsored work projects targeting roads near nuclear power plants in the Midwest. To be updated in 1994.

Midwestern States Highway Routing Report, November 1991, 16 pages, DOE/CH/10402-10. This report identifies those agencies in Midwestern states that hold specific authority to designate alternatives to the preferred routes established under federal guidelines for transporting high-level radioactive waste.

Timing and Funding of Emergency Response Training in Midwestern States, November 1991, 14 pages, DOE $/ \mathrm{CH} / 10402-14$. By providing information on critical lead times for planning and delivering emergency response training courses in Midwestern states, this report provides a basis for determining the appropriate time to begin federal training assistance mandated by the Nuclear Waste Policy Act. To be updated in 1994.

Radioactive Materials Transportation Safety Training Report, May 1990, 16 pages, DOE/CH/ 1(102-3. This report looks at Midwestern state programs for training emergency response personnel to handle transportation accidents involving radioactive materials. To be updated in 1994. 
